\title{
COP and the Cloth: Quantitatively and Normatively Assessing Religious NGO Participation at the Conference of Parties to the United Nations Framework Convention on Climate Change
}

\author{
David Krantz 1,2
}

Citation: Krantz, D. COP and the

Cloth: Quantitatively and

Normatively Assessing Religious NGO Participation at the Conference of Parties to the United Nations Framework Convention on Climate Change. Sci 2021, 3, 24. https:// doi.org/10.3390/sci3020024

Academic Editor: Miguel Amado

Received: 10 May 2021

Accepted: 2 April 2021

Published: 28 April 2021

Publisher's Note: MDPI stays neutral with regard to jurisdictional claims in published maps and institutional affiliations.

Copyright: (C) 2021 by the author. Licensee MDPI, Basel, Switzerland. This article is an open access article distributed under the terms and conditions of the Creative Commons Attribution (CC BY) license (https:// creativecommons.org/licenses/by/ $4.0 /)$.
1 School of Sustainability, College of Global Futures, Julie Ann Wrigley Global Futures Laboratory, Arizona State University, Tempe, AZ 85281, USA; krantz@asu.edu

2 Center for Energy \& Society, School for the Future of Innovation in Society, College of Global Futures, Julie Ann Wrigley Global Futures Laboratory, Arizona State University, Tempe, AZ 85281, USA

\begin{abstract}
How much is religion quantitatively involved in global climate politics? After assessing the role of the Conference of Parties to the United Nations Framework Convention on Climate Change from a normative perspective, this descriptive, transdisciplinary and unconventional study offers the first comprehensive quantitative examination of religious nongovernmental organizations that formally participate in its annual meetings, the largest attempts to solve the climate crisis through global governance. This study finds that although their numbers are growing, only about 3 percent of registered nongovernmental organizations accredited to participate in the conference are overtly religious in nature-and that more than 80 percent of those faith-based groups are Christian. Additionally, this study finds that religious nongovernmental organizations that participate in the conference are mostly from the Global North. The results call for greater participation of religious institutions in the international climate negotiations in order for society to address the planetary emergency of climate change.
\end{abstract}

Keywords: civil society; climate politics; environmental governance; faith-based environmentalism; faith-based nonprofits; global governance; international relations; religion and ecology; religion and society; sustainability

\section{Introduction}

The United Nations has built the annual meeting of the Conference of Parties (COP) ${ }^{i, i i, i i i}$ to the United Nations Framework Convention on Climate Change (UNFCCC) ${ }^{\mathrm{iv}}$ into the preeminent international arena for addressing climate change and its related problems through global climate politics. Although one previous study, as will be discussed later in this paper, researched quantitative participation of religious groups at the COP [1], this new study constitutes the first comprehensive published attempt to determine the religious constituency of UNFCCC-accredited nongovernmental organizations (NGOs). Given both their reach as well as their status as ethical authorities, religious institutions-and their leaders as people of the cloth, which I use here as a generic representative of a vestment of faith-are in a strong (and at this point largely unexercised) position to lead the world in environmental action [2]. The 2015 papal encyclical on climate change, Laudato Si: On Care for Our Common Home [3], brought renewed attention to the potential of religion to impact global climate-change policy, but this paper asks: In what numbers do religious organizations participate in the COP?

My research question invites several critiques: (i) Why include a normative perspective? (ii) Why is the COP important? (iii) Why is it important for religion to be involved in policy? (iv) Is not religion anti-environmental and therefore worthy of blame [4]? (v) Lastly, would not the qualitative aspects of the role of religion at the COP be more important and 
potentially more interesting than the quantitative aspects? In other words, why does this study matter?

Regarding normativity, since we all have our own unique backgrounds and implicit and explicit biases, the ideal of objectivity may be unachievable, attempting but ultimately failing to hide our normative perspectives [5]. Accordingly, I see explicitly normative perspectives as more transparent, and I recognize that others have different points of view on this (and virtually everything else) [6]. Preference for or against normativity is subjective. Moreover, normative scholarship is becoming increasingly common in some fields such as international relations [7-12], particularly when the object of inquiry relates to morals and ethics [7] — and some newer fields, such as sustainability, which "requires both a descriptive knowledge and a normative approach" [13], place normativity at the heart of their raisons d'être.

In Section 2, I offer a normative assessment of the role of the COP. I address the role of religion in policy in Section 3 as part of my discussion of existing thoughts and literature on the participation of religious NGOs in the political realm of the United Nations.

The academic perception of religion as anti-environmental stems from historian Lynn White Jr.'s prominent narrative of religion as the root cause of the ecological crisis [4]. However, White focused on Christianity ${ }^{v}$ and provided little to no empirical evidence for his critique. Even if one thinks White was right, then the crisis's "ultimate solution would have to be spiritual and religious" [14] as well. As academics have been debating White's thesis since it was published more than 50 years ago [15-18] —indeed, White unintentionally may have become the catalyst for Arne Næss's deep ecology [19] as well as the fields of ecotheology, environmental ethics, and religion and ecology [20]—studying the numeric participation of religious NGOs at the COP may provide further quantitative evidence to either support or rebuke White's claim.

As far as the final concern, there are several reasons that this study's quantitative approach matters. Firstly, quantitative data are specific, replicable and comparable. This study continues a body of scholarship examining the numeric participation of NGOs in U.N. bodies [1,21-24] by providing the first comprehensive attempt to quantitatively assess religious NGOs in the UNFCCC and at the COP. As others have argued in studying the numeric participation of religious groups at the ECOSOC, the United Nations Economic and Social Council ${ }^{\mathrm{vi}}$ - the focus of previous quantitative studies on religious NGOs at the United Nations-delineating the quantitative aspects of participation can lay the groundwork for later qualitative research [21,22]. Furthermore, discerning the scope of interaction between international institutions may be key to comprehending globalization, or the new world order [25]. In other words, quantitative research can help provide the basis for future qualitative research - and when combined, quantitative and qualitative research offer a more holistic understanding of an issue. Subjects for future research include how and why religious NGO activities, motivations and goals differ from secular NGOs; if and how religious and secular NGOs work together; why religious NGO participation has changed over time; the role of religious doctrine in that change; and the corresponding political and social implications and impacts.

This paper is the first in a series of two studies. The second takes a qualitative approach to examine the methods and goals of religious NGOs at the COP [26]. Together these two studies help illustrate the role of religion at the COP. How exactly this study's quantitative work was undertaken is described in Section 4, with results detailed in Section 5. Most significantly, this study finds that:

- Only about 3 percent of UNFCCC-accredited NGOs are religious in nature;

- More than 80 percent of those faith-based groups are Christian;

- Most are from the Global North; and

- Religious NGOs participate in the UNFCCC at a much lower rate than in the ECOSOC.

After a discussion (Section 6), I will conclude (Section 7) with a moral call to action for more religious NGOs to participate in the COP in order for society to help address the planetary emergency of climate change. 


\section{The COP and the UNFCCC: A Normative Assessment}

At the dawn of the epoch in which humans have become the most impactful force shaping the Earth [27-29] —alternatively called the atomicocene, capitalocene, chthulucene, corporatocene, eremocene, homocene, homogenocene, neganthropocene, plantationocene, sustainocene, technocene, urbanocene, and about 100 other names, but most commonly known as the anthropocene [30-32] — anthropogenic climate change and other forms of environmental destruction may be the biggest challenge ever faced by humanity: a "planetary emergency" [33-37]. Every year since the first COP in 1995, politicians and other representatives from world governments have gathered annually with the goal of addressing climate change, caused predominantly through excessive carbon emissions from human society. After a week or two of talking about how to address a global problem requiring unprecedented urgency, world leaders return home and, for the most part ${ }^{\mathrm{vii}}$, continue discussions at the COP the following year. In essence, glacial politics abets glacial melt. The COP proves that the "Madhouse Effect" - where the "very language of science itself, of 'skepticism' and 'evidence,' is used in a way opposite of how science really employs it" [38] — can extend even to those who supposedly accept the science of climate change and are supposedly meeting explicitly to remedy it ${ }^{\mathrm{viii}}$.

In addressing the United Nations, teenage climate activist Greta Thunberg offered a succinct critique not of the COP specifically but of world leadership's absence of action on the issue: "People are suffering. People are dying. Entire ecosystems are collapsing. We are in the beginning of a mass extinction. And all you can talk about is money and fairytales of eternal economic growth" [39].

Thunberg may be quite effective at motivating the public [40], but governments at the COP seem to be immune to the "Greta Effect" that inspires others to action. The prevailing sentiment of nations at the COP may be best embodied by the so-called "anti-Greta"Naomi Seibt, the German teenager working for the Heartland Institute, a U.S.-based libertarian think tank notorious for climate denialism - who has described the thinking of those like Thunberg as "despicably anti-human" [41]. Seibt essentially says that she does not want people to stop believing in anthropogenic climate change, she simply wants people to stop thinking that they actually should do anything about it [42]. Or, in the parlance of supporters of the James Partnership's Cornwall Alliance for the Stewardship of Creation - the libertarian and evangelical Christian group whose members believe that Earth stewardship requires exploitation of fossil fuels, and which is funded by Chevron, ExxonMobil, the Koch brothers and the Scaife family, the heirs to Gulf Oil-Seibt and the climate delayers at the COP are "resisting the green dragon" [43-45]. Their climate delayism constitutes a form of normalcy bias ${ }^{\text {ix }}$, the belief that everything will be fine in the future as it is perceived to be in the present, despite facts to the contrary, leading to inadequate and inappropriate response to a hazard.

The COP—which also includes corporations, educational institutions and other NGOs, that together constitute civil society - has resulted in slow, incremental shifts toward reining in carbon emissions, including, most notably, the Kyoto Protocol in 1997 and the Paris Agreement in 2015. Perhaps newly revived leadership from the United States under Pres. Joseph Biden will quicken the pace of change, but to date the COP clearly has failed to gain the substantial reductions in carbon emissions necessary to avert climate change [46-55]. Indeed, global carbon emissions have been climbing steadily and have nearly doubled since COP 1 in Berlin [56] and at least 148 countries, including China, India and the United States, are not even on target to meet the modest carbon-reduction goals set by the Paris Agreement [57]. The result is that the COP has the effectiveness of Keystone Cops ${ }^{\mathrm{x}}$. Instead of taking action to drastically reduce emissions, we have been throwing more coal into the fire that our increasingly off-kilter climate is becoming—or as my former teacher Wallace Broecker, among the first to warn of global warming and climate change [58], famously quipped, "the climate system is an angry beast and we are poking it with sticks" [59].

The COP is also a behemoth-dense and difficult to penetrate with tens of thousands of people with competing interests in attendance [60], including negotiators from every 
country in the world. That makes the COP, however ineffective, the most significant global effort for countries to address climate change on an international level.

In summary, the COP has been ineffective to date, but it represents a complex solution to a complex problem. Solutions to the problems of the anthropocene, such as climate change, are likely as complex and multifaceted as the problems themselves. And of the many possible approaches, religion may be a significantly underutilized leverage point [61] in developing sustainable solutions [62-67].

\section{Religious NGOs at the United Nations}

Academics have many names for religious organizations. Katharina Glaab uses the term faith-based actors, or FBAs [68], Jeffrey Haynes uses the term faith-based organizations, or FBOs [69], and others have called these RNGOs [22,70,71], mimicking the naming pattern used in U.N. proceedings. I prefer the term religious groups or religious NGOs $[23,25,72]$ because it closely mirrors official UNFCCC terminology while eschewing the abbreviation RNGOs because RNGOs also has been used to refer to regional NGOs, and to avoid confusion with RINGOs, the UNFCCC constituency group of researchers. Nonetheless, I use all these terms and others interchangeably as they all represent the same categorical grouping.

One might argue that this research views religion as instrumental to a secular cause (namely, addressing climate change) rather than to an overtly religious purpose, such as spiritual ascent, enlightenment and/or serving one or more deities (the Divine). From my personal perspective, the purpose of religion, or at least prosocial religion, whether developed by humans or the Divine, is to make better humans [73,74] (although of course religion is not the only path to human betterment) —and thereby thrive as a species [75-78]. Therefore I see religion as inherently instrumental (as designed by humans or the Divine), and to the extent that its practice leads to better humans it succeed ${ }^{\mathrm{xi}}$, and to the extent that its practice leads to worse (or antisocial) human behavior (such as by instigating violence on fellow humans and/or nature) it fails.

To those who ask if "the movement of religious organizations into a secular field constitute[s] an increase in the public exercise of religious authority or, instead, the secularization of religious NGOs" [79], I note that religions always have encompassed both the overtly religious and the seemingly secular, in that they seek to instruct their practitioners how to live. Correspondingly, religious laws and edicts typically are not restricted to overt religious practice- the activities that help differentiate one religion from another and from secular society - and include seemingly secular laws. For example, in Abrahamic faith traditions the Hebrew Bible prohibits murder (Gen. 9:6, Ex. 20:13), imposes empathy (Lev. 19:18), and commands stewardship of the Earth (Gen. 2:15). Ahimsāa, aka Ahinsa-a nonviolence principle shared by Buddhism, Hinduism and Jainism-calls for gently walking on the Earth, leading ascetic Jains, for example, to sweep the ground before their steps in order to minimize their chances of injuring insects with their feet. Around the world, the spiritual traditions of indigenous peoples do not differentiate between the sacred and the profane-everything in the world is seen as connected-allowing spirituality to fill every action. Indeed, in native traditions, "the Western dichotomies of natural vs. super-natural, physical vs. metaphysical, sacred and profane, nature vs. nurture become largely meaningless" [80]. As the list of religious laws governing the seemingly secular can be longer than the list of laws that govern the overtly religious, I argue "that all acts dictated or inspired by religion —not just those that seem overtly religious, such as attending religious services or observing religious dietary laws-are religious acts using religious methods by virtue of their religious origin" [81]. Acts that may not overtly seem religious still can be sacred because they are part of the religion's mores [82]. Therefore an act can be religious by virtue of its inspiration, regardless of whether or not it may seem like an overtly religious act to others. While not every religious NGO necessarily would describe it this way [83], this study covers overtly religious NGOs performing seemingly non-overtly religious practice. 
Religious NGOs that participate in secular political systems, such as the UNFCCC, are not "water[ing] down" their religions [84], since the seemingly secular issues on which they remark are part of their own faith traditions. Religious NGOs also need not be doing so as either a "public exercise of religious authority" [79] or as a "secularization of religious NGOs" [79] but rather as an inclusion-not assertion-of religious mores into discussions that affect their adherents. In essence, church and state can remain separate-church (used here as a common reference to religion in general) can operate independently outside of the state while providing counsel to the state, a perspective perhaps best voiced by the Rev. Martin Luther King Jr., who said that the church "is not the master or the servant of the state, but rather the conscience of the state. It must be the guide and the critic of the state" [85]. One cannot be the conscience of the state standing by idly; being the state's conscience requires active engagement with the state. Likewise, being the conscience of the UNFCCC requires active engagement with it, which in turn requires formal accreditation.

Many arms of the United Nations maintain their own separate accreditations. Even though the UNFCCC allows for nine constituency groups ${ }^{\text {xii }}$ to provide input into COP negotiations, not one of the nine-agricultural, business, environmental, indigenous, local governmental, researcher (higher education), trade union, women and gender, and youth [86] - represents religion. Determining a de-facto UNFCCC constituency group for religion requires digging into UNFCCC accreditation and registration numbers.

\section{Methods}

In designing this study to examine the religious makeup of UNFCCC-accredited NGOs, I adapted the methods of Ann-Kristin Beinlich and Clara Braungart, who examined the religious makeup of ECOSOC-accredited NGOs [21], and this paper notes the instances of where and why my methodology differs from theirs. Using publicly available data provided by the UNFCCC [87], I analyzed all UNFCCC-accredited NGOs as of 1 May $2019^{x i i i}$ to determine religiosity, using Beinlich and Braungart's definition of religious groups as those that "evoke, implicitly or explicitly, religious, spiritual, or faith-based symbology" [21].

The UNFCCC, like other arms of the United Nations, does not publish the religious affiliation of accredited NGOs. Because of that, my study classified UNFCCC-accredited NGOs as religious only by their overtness. Whereas Beinlich and Braungart determined a group's religiosity through review of its mission statement and website, my study relied nearly exclusively upon a group's name. Those NGOs that are religious but operate under seemingly secular names were classified by my study as secular and not religious ${ }^{\text {xiv }}$. I made this choice partly because many of the groups do not have operational websites, and because I found that Beinlich and Braungart's method led to some fuzzy classifications, such as determining that a group was religious because of usage of the word "Creator" at the end of a long and otherwise secular about-us website statement [21,88]. However using the same standard, the U.S. Department of the Treasury would be a religious group through its emblazoning of "In God We Trust" on all American currency. And while one could make an argument that the United States, despite its promise of separation of church and state, is indeed a religious institution, as U.S. Supreme Court Justice David Josiah Brewer did at the turn of the 20th century ${ }^{\mathrm{XV}}$ [89], fuzzy grey areas do not lend themselves well to consistent and replicable classification. By choosing to focus on those groups that are overtly religious in nature - those that overtly self-identify as a religious/faith-based/spiritual institution rather than those who may simply utilize religion tangentially-I removed much of the potential ambiguity in categorical classification ${ }^{\mathrm{xv}}$, and although the result may be more minimalist than maximalist, it also may be more consistent, replicable and unambiguous.

Alternatively, a survey of the thousands of UNFCCC-accredited NGOs may lead to some groups without overtly religious names self-reporting as religious, but a survey most likely would yield a sample rather than the entire population, since assuredly many groups would not participate. That sample may contain bad data as questions asked later in a survey are susceptible to misclassification and other reporting errors due to 
response fatigue [90]. Those who do respond may represent only a small percentage of the population thanks to survey fatigue [91]. For example, in 2011 a University of Kent team attempted to survey 3,275 NGOs at the U.N. Department of Global Communications ${ }^{\text {xvii, }}$ then known as the U.N. Department of Public Information, or the DPI. However only 192-a non-randomized sample of less than 6 percent of DPI-accredited NGOs-responded to the survey [92]. The result was unrepresentative of the population ${ }^{\text {xviii }}$ and, by the team's own admission, skewed even more Christian than more representative studies indicate.

Additionally, a survey on religious groups can yield different results because of different understandings of the term "religious." While used here as meaning of or pertaining to religion, the term to others can convey a fervency associated with the most orthodox of a religion's practitioners. Therefore a religious NGO may be of or pertaining to a specific religion and not consider itself religious [22] ${ }^{\mathrm{xix}}$, per se, because the group represents a progressive, pluralistic and/or nonsectarian faction of the faith.

Eschewing a survey and using Beinlich and Braungart's method instead, I built a database of a group's name, city, country, type of religious orientation, religious denomination (if applicable and discernable), website (if available), whether or not it is an institution of higher learning, and contact information (if available). Following Beinlich and Braungart, religious categorization excluded governmental and quasi-governmental religious institutions (such as Keren Kayamet L'Yisrael ${ }^{\mathrm{xx}}$ ) and secular groups from countries (such as Cambodia, Iran, Israel and the Vatican) that are defined by their religion. I also excluded intergovernmental organizations ${ }^{x \times i}$, such as the European Investment Bank, because they do not represent civil society. My study has made no distinction between faith traditions, religions and spiritual movements (such as the Brahma Kumaris World Spiritual University—henceforth simply Brahma Kumaris—which does not self-identify as a religion). When determining the continental status of NGOs, my study used the location of the country's capital city ${ }^{\text {xxii, } x \text { xiii, xxiv }}$.

Lastly, just because a group becomes accredited with the DPI, ECOSOC or the UNFCCC does not mean that it actually engages with the work of the accrediting agency; accreditation simply makes the group eligible to engage. In other words, just because an NGO is accredited by the UNFCCC does not mean that it actually sends representatives to the COP. Prior studies of ECOSOC-accredited NGOs relied on U.N.-agency accreditation lists, meaning that they really only measured eligibility to participate, rather than actual participation. My study of UNFCCC-accredited NGOs looks deeper to also examine the affiliation of individuals who registered to attend the COP.

Using publicly available data provided by the UNFCCC [93], I built a second database of all individuals who registered to participate in COP 24 held in Katowice, Poland, in December 2018. I chose COP 24 instead of COP 25 because the latter's location, which originally was Brazil, moved at first to Chile ${ }^{\mathrm{xxv}}$ and, a mere few weeks before the conference's start, moved once again to Spain, making COP 25 representation a less reliable proxy for religious participation since many organizations-particularly small groups-with flights and lodging already arranged for Chile, may not have been able to quickly adjust plans for Spain instead.

From my second database, I selected for individuals who were registered as representatives of religious NGOs and developed a spreadsheet of formal religious organizational involvement at COP 24. The database excludes individuals who represented religious NGOs at COP 24 but who did not register for COP 24 as the representative of a religious NGO. Also, although it is likely that some people registered for COP 24 but did not actually attend the event, a list of individuals who picked up their badges at COP 24 is not publicly available. Additionally, it is worth noting that most COPs have two security-separated zones-one for registered attendees representing UNFCCC-accredited institutions, and one for the general public. While historically the public zone has not required registration, it has recently, and those registration lists are not publicly available and therefore are excluded from this study. 


\section{Results}

This study found that as of May 2019, there were 2,222 UNFCCC-accredited NGOs, 57 of which, or about 3 percent, are overtly religious ${ }^{x \times v i}$, as listed in Appendix A. Of those, as shown in Table 1, this study found that 47, or about 82 percent, are Christian; four, or about 7 percent, are interfaith/multifaith; two, or about 4 percent, are Bahá'í; two, or about 4 percent, are Buddhist; one, or about 2 percent, is Brahma Kumaris; and one, or about 2 percent, is indigenous spiritual. Completely absent are major world religions such as Daoism/Taoism, Hinduism, Islam, Jainism, Judaism, Shintoism, Sikhism and Zoroastrianism $^{\text {xxvii }}$.

Table 1. UNFCCC-accredited religious NGOs.

\begin{tabular}{cccc}
\hline Faith & $\begin{array}{c}\text { Number } \\
\text { of Accredited NGOs }\end{array}$ & $\begin{array}{c}\text { Percentage } \\
\text { of Religious NGOs }\end{array}$ & $\begin{array}{c}\text { Percentage } \\
\text { of All NGOs }\end{array}$ \\
\hline Bahá'í & 2 & $3.51 \%$ & $0.09 \%$ \\
Brahma Kumaris & 1 & $1.75 \%$ & $0.05 \%$ \\
Buddhism & 2 & $3.51 \%$ & $0.09 \%$ \\
Christian & 47 & $82.46 \%$ & $2.12 \%$ \\
Daoism/Taoism & 0 & $0 \%$ & $0 \%$ \\
Hinduism & 0 & $0 \%$ & $0 \%$ \\
Interfaith/multifaith & 4 & $7.02 \%$ & $0.18 \%$ \\
Indigenous spiritual & 1 & $1.75 \%$ & $0.05 \%$ \\
Islam & 0 & $0 \%$ & $0 \%$ \\
Jainism & 0 & $0 \%$ & $0 \%$ \\
Judaism & 0 & $0 \%$ & $0 \%$ \\
Shintoism & 0 & $0 \%$ & $0 \%$ \\
Sikhism & 0 & $0 \%$ & $0 \%$ \\
Zoroastrianism & 0 & $0 \%$ & $0 \%$
\end{tabular}

${ }^{1}$ Numbers do not equal total due to rounding.

Examining the organizational affiliation of COP 24 registrants may offer a more accurate understanding of which religious groups participate at the COP. This study found that $22,770^{x x v i i i}$ individuals registered to participate from 2,168 groups, including:

- $\quad 13,890$ individuals from 197 registered parties, aka world governments;

- 6,046 individuals from 1,120 registered NGOs;

- $\quad 1,541$ individuals from 726 registered media organizations;

- 791 individuals from 80 registered intergovernmental organizations, such as the International Federation of Red Cross and Red Crescent Societies and the International Renewable Energy Agency, as well as the International Potato Center, and the Organization of the Petroleum Exporting Countries (OPEC);

- 267 individuals from 19 registered specialized agencies, such as the World Bank and the International Monetary Fund;

- 227 individuals from 25 U.N. groups; and

- $\quad$ Eight individuals from one observer state, the Holy See, aka the Vatican.

Within the NGO numbers, this study found that there were 220 individuals representing 42 religious NGOs, accounting for about 4 percent of all NGO-registered individuals and about 4 percent of NGOs among COP 24 registrants. About three-quarters of UNFCCCaccredited religious NGOs sent representatives to COP 24, but the high participation rate only increased religious-NGO representation at COP 24 by a percentage point from the 3 percent share of religious NGOs among all UNFCCC-accredited NGOs. Additionally, this study found another 29 individuals representing religious NGOs who registered under a different NGO than their own, including 21 who registered under a fellow religious NGO and eight who registered under a secular NGO. Those 29 registered as representatives of 25 NGOs, nine of which already were registered, effectively adding 16 to the tally of 
religious NGOs formally registered to participate in COP 24. As shown in Table 2 and listed in Appendix B, counting those religious NGOs that registered under the auspices of other NGOs brings the number of different religious NGOs at COP 24 to 58 , of which 47 , or about 81 percent, are Christian; six, or about 10 percent are interfaith/multifaith; three, or about 5 percent, are Buddhist; one, or about 2 percent, is Brahma Kumaris; and one, or about 2 percent, is indigenous spiritual.

Table 2. Religious NGOs at COP 24.

\begin{tabular}{cccc}
\hline Faith & $\begin{array}{c}\text { Number } \\
\text { of Registered NGOs }\end{array}$ & $\begin{array}{c}\text { Percentage } \\
\text { of Religious NGOs }\end{array}$ & $\begin{array}{c}\text { Percentage } \\
\text { of All NGOs }\end{array}$ \\
\hline Bahá'í & 0 & $0 \%$ & $0 \%$ \\
Brahma Kumaris & 1 & $1.72 \%$ & $0.09 \%$ \\
Buddhism & 3 & $5.17 \%$ & $0.27 \%$ \\
Christian & 47 & $81.03 \%$ & $4.20 \%$ \\
Daoism/Taoism & 0 & $0 \%$ & $0 \%$ \\
Hinduism & 0 & $0 \%$ & $0 \%$ \\
Interfaith/multifaith & 6 & $10.34 \%$ & $0.54 \%$ \\
Indigenous spiritual & 1 & $1.72 \%$ & $0.09 \%$ \\
Islam & 0 & $0 \%$ & $0 \%$ \\
Jainism & 0 & $0 \%$ & $0 \%$ \\
Judaism & 0 & $0 \%$ & $0 \%$ \\
Shintoism & 0 & $0 \%$ & $0 \%$ \\
Sikhism & 0 & $0 \%$ & $0 \%$ \\
Zoroastrianism & 0 & $0 \%$ & $5.18 \%{ }^{2}$ \\
\hline Total & 58 & $100 \%{ }^{2}$ & $\%$ \\
\hline
\end{tabular}

${ }^{1}$ Compares the number of religious NGOs including those that registered under the auspices of other NGOs to the total number of registered NGOs $(1,120)$, excluding those secular groups that registered under the auspices of other NGOs; ${ }^{2}$ Numbers do not equal total due to rounding.

However different groups brought different numbers of representatives to COP 24 . For example, while the World Alliance of Young Men's Christian Associations registered 16, Micah Zambia registered only one, and that was through its fellow Christian organization Tearfund, since Micah Zambia is not accredited by the UNFCCC.

As shown in Table 3, of the total of 249 individuals representing religious NGOs, 205, or about 82 percent were representing Christian groups; 18, or about 7 percent, were representing Buddhist groups; 16, or about 6 percent, were representing interfaith/multifaith groups; seven, or about 3 percent, were representing Brahma Kumaris groups; and three, or about 1 percent, were representing indigenous-spiritual groups. Groups from other faith traditions did not formally register representatives to attend COP 24.

In total the 249 individuals representing religious NGOs also constituted about 4 percent of all NGO-registered individuals at COP 24. These percentages are close to the representation of faiths among UNFCCC-accredited religious NGOs, with a few notable exceptions. While Buddhist groups make up only about 4 percent of UNFCCC-accredited religious NGOs, about 7 percent of individuals representing religious NGOs at COP 24 were affiliated with Buddhist groups. While about 4 percent of UNFCCC-accredited NGOs are Bahá'í, they did not register any representatives for COP 24. Still, those differences are not that large, and even though some organizations brought many more representatives to COP 24 than others, and more religious NGOs were represented at COP 24 than were accredited by the UNFCCC, the overall distribution of different faith groups that registered to attend remained, with exceptions noted, relatively unchanged as compared to the distribution of faith groups accredited by the UNFCCC.

In terms of geography, as shown in Table 4, this study found that 895 , or about 40 percent, of UNFCCC-accredited NGOs—-both religious and secular-are based in Europe; 612, or about 28 percent, are based in North America; 331, or about 15 percent, are based in 
Asia; 192, or about 9 percent, are based in Africa; 121, or about 5 percent, are based in South America; and 71, or about 3 percent, are based in Australia and Oceania ${ }^{x x i x}$.

Table 3. Individuals representing religious NGOs at COP 24.

\begin{tabular}{cccc}
\hline Faith & $\begin{array}{c}\text { Number of } \\
\text { Registered } \\
\text { Individuals }\end{array}$ & $\begin{array}{c}\text { Percentage of } \\
\text { Religious-NGO } \\
\text { Individuals }\end{array}$ & $\begin{array}{c}\text { Percentage of All } \\
\text { NGO Individuals }\end{array}$ \\
\hline Bahá'í & 0 & $0 \%$ & $0 \%$ \\
Brahma Kumaris & 7 & $2.81 \%$ & $0.12 \%$ \\
Buddhism & 18 & $7.23 \%$ & $0.30 \%$ \\
Christian & 205 & $82.33 \%$ & $3.39 \%$ \\
Daoism/Taoism & 0 & $0 \%$ & $0 \%$ \\
Hinduism & 0 & $0 \%$ & $0 \%$ \\
Interfaith/multifaith & 16 & $6.43 \%$ & $0.26 \%$ \\
Indigenous spiritual & 3 & $1.20 \%$ & $0.05 \%$ \\
Islam & 0 & $0 \%$ & $0 \%$ \\
Jainism & 0 & $0 \%$ & $0 \%$ \\
Judaism & 0 & $0 \%$ & $0 \%$ \\
Shintoism & 0 & $0 \%$ & $0 \%$ \\
Sikhism & 0 & $0 \%$ & $0 \%$ \\
Zoroastrianism & 0 & $0 \%$ & $0 \%$ \\
\hline Total & 249 & $100 \%$ & $4.12 \% 1$ \\
\hline
\end{tabular}

${ }^{1}$ Numbers do not equal total due to rounding.

Table 4. Geographic distribution of UNFCCC-accredited NGOs.

\begin{tabular}{ccccc}
\hline Continent & $\begin{array}{c}\text { Total Accredited } \\
\text { NGOs }\end{array}$ & Percentage of Total & $\begin{array}{c}\text { Number of Accredited } \\
\text { Religious NGOs }\end{array}$ & $\begin{array}{c}\text { Percentage of } \\
\text { Religious NGOs }\end{array}$ \\
\hline Africa & 192 & $8.64 \%$ & 6 & $10.53 \%$ \\
Antarctica & 0 & $0 \%$ & 0 & $0 \%$ \\
Asia & 331 & $14.90 \%$ & 5 & $0.77 \%$ \\
Australia \& Oceania & 71 & $3.20 \%$ & 0 & $45.61 \%$ \\
Europe & 895 & $40.28 \%$ & 26 & $35.09 \%$ \\
North America & 612 & $27.54 \%$ & 20 & $0 \%$ \\
South America & 121 & $5.45 \%$ & 0 & $100 \%$ \\
\hline Total & 2,222 & $100 \% 1$ & 57 & \\
\hline
\end{tabular}

${ }^{1}$ Numbers do not equal total due to rounding.

Of the 57 UNFCCC-accredited religious NGOs, 26, or about 46 percent, are based in Europe; 20, or about 35 percent, are based in North America; six, or about 11 percent, are based in Africa; five, or about 9 percent, are based in Asia; and none are based in South America or Australia and Oceania. UNFCCC-accredited religious NGOs are more heavily concentrated in the Global North than UNFCCC-accredited NGOs at large.

\section{Discussion}

The results of this study compare interestingly to previous studies on religious participation in the ECOSOC as well as to the one previous, but limited, quantitative study on religious participation in the UNFCCC.

After COP 15 in Copenhagen in 2009, Miquel Muñoz Cabré researched all UNFCCCaccredited NGOs that participated in the COPs from 1995 to 2009 and classified them into 22 categories that basically expanded upon the nine categories employed by the UNFCCC. One of those 22 was religion, and Cabré identified 1,322 UNFCCC-accredited NGOs, of which he classified 25 (or about 2 percent) as religious [1]. He did not break down those 25 by type of religious group or by geography. Further, he did not allow for groups to exist in more than one category. For example, he might have classified a religious NGO that works 
on human rights under the human-rights category and not under the religion category, resulting in what could have been an undercount of religious NGOs.

Glaab, et al., argue that the number of religious groups participating in the UNFCCC is inconsequential since it does not account for the size and influence of individual groups, in that a single group may be far larger and therefore more influential than dozens of groups combined. They point to the World Council of Churches, which says it represents more than 500 million people through 350 Christian denominations, but counts as one organization [70,94]. However the size of the World Council of Churches is an outlier, and there are similar secular umbrella groups of substantial influence that are accredited by the UNFCCC, such as the International Association of Oil and Gas Producers ${ }^{\mathrm{xxx}}$, a trade group whose membership includes scores of the largest petroleum companies in the world, including BP, Chevron, ConocoPhillips, ExxonMobil, Hess, Petrobras and Saudi Aramco [95].

The number of religious groups participating in the UNFCCC matters because it provides a proxy for diversity of involved religions and a proxy for level of involvement. Furthermore, Glaab, et al., report that the Interfaith Liaison Committee-a semi-informal group recognized by the UNFCCC to effectively operate in place of a formal UNFCCC constituency for religion-self-identifies 50 member groups but by the calculations of Glaab and her colleagues there are only around 30 member groups [70], possibly an undercount. (Glaab, et al., did not provide a breakdown of their estimate by faith but said that most of the groups were Christian.) My study was designed to assess the involvement of religious NGOs at the COP outside of and including those who participate in the activities of the Interfaith Liaison Committee.

The number of UNFCCC-accredited religious NGOs (57) in my study increased by about 128 percent from the 25 that Cabré found in his study of 1995-2009 data. The total number of UNFCCC-accredited NGOs grew as well, just not as drastically, increasing by about 68 percent from 1,322 to 2,222. That finding differs from the conclusion of Beinlich and Braungart, who determined that ECOSOC-accredited religious groups grew at about the same rate as ECOSOC-accredited secular groups, contrary to conventional opinion that religion is on the rise [21].

However the 2,222 includes 247 universities and other institutions of higher learning. It may not be fair to include those since, even if they included religious universities (and indeed there is one such institution accredited), one may not reasonably expect universities and other institutions of higher learning to potentially promote a cause or participate for any other reason than allowing an avenue for its professors and students to conduct research. While all individuals who participate in the COP through UNFCCC-accredited NGOs are termed "observers," the higher-education affiliated researchers may be the only ones whose participation is mostly limited to observation. Removing universities and other institutions of higher learning, however, leaves the percentages virtually unchanged: 1,975 NGOs, 56 of which, or still about 3 percent, are overtly religious.

By comparison, as shown in Tables 5 and 6, a handful of studies have examined ECOSOC accreditation of religious NGOs, although none earlier than 2000. While the ECOSOC formed in the 1960s and quickly attracted enough religious NGOs to spark the founding of the Committee of Religious NGOs at the United Nations in 1972 [96,97], quantitative typologies of religious NGOs engaging with the United Nations date back to only the past two decades - dovetailing with a shift in public perception of socio-religious engagement from unwelcome to desirable [96], the beginnings of a shift from seeing religion as an environmental opponent to a potential environmental ally.

In 2000, Geoffrey Knox headed a team that found 2,000 ECOSOC-accredited NGOs, of which they identified 180, or about 9 percent, as religious. Of those ECOSOC-accredited religious groups, they found that 61 percent were Christian, 15 percent Islamic, 8 percent were interfaith/multifaith, 7 percent were Jewish, and 9 percent were what they labeled as an undefined "other" [24]. 
Table 5. NGO accreditation at the DPI, the ECOSOC, the UNFCCC and the COP over time.

\begin{tabular}{|c|c|c|c|}
\hline U.N. Entity & $\begin{array}{c}\text { Number of Accredited } \\
\text { NGOs }\end{array}$ & $\begin{array}{c}\text { Number of Accredited } \\
\text { Religious NGOs }\end{array}$ & $\begin{array}{l}\text { Religious NGOs as } \\
\text { Percentage of Total }\end{array}$ \\
\hline ECOSOC (2000) ${ }^{1}$ & 2,000 & 180 & $9.00 \%$ \\
\hline ECOSOC (2003) ${ }^{2}$ & 2,060 & 175 & $8.50 \%$ \\
\hline DPI (2003) ${ }^{2}$ & 1,460 & 184 & $12.60 \%$ \\
\hline ECOSOC $(2008)^{3}$ & 3,183 & 320 & $10.05 \%$ \\
\hline ECOSOC (2012) ${ }^{4}$ & 3,937 & 339 & $8.61 \%$ \\
\hline UNFCCC (2009) ${ }^{5}$ & 1,322 & 25 & $1.89 \%$ \\
\hline UNFCCC (2019) & 2,222 & 57 & $2.57 \%$ \\
\hline UNFCCC (2019) 6 & 1,975 & 56 & $2.84 \%$ \\
\hline $\begin{array}{l}\text { COP Interfaith Liaison } \\
\text { Committee }(2013-15)^{7}\end{array}$ & $\mathrm{~N} / \mathrm{A}$ & $\sim 30$ & $\mathrm{~N} / \mathrm{A}$ \\
\hline COP $24(2018)$ & 1,120 & 42 & $3.75 \%$ \\
\hline COP $24(2018)^{8}$ & 1,120 & 58 & $5.18 \%$ \\
\hline
\end{tabular}

${ }^{1}$ Source: [24]; ${ }^{2}$ Source: [22]; ${ }^{3}$ Source: [23]; ${ }^{4}$ Source: [21]; ${ }^{5}$ Source: $[1] ;{ }^{6}$ Excluding universities and other institutions of higher learning;

${ }^{7}$ Source: $[70] ;{ }^{8}$ Compares the number of religious NGOs including those that registered under the auspices of other NGOs to the total number of registered NGOs, excluding those secular groups that registered under the auspices of other NGOs.

Table 6. Representation of religious NGOs at the DPI, the ECOSOC and the UNFCCC over time.

\begin{tabular}{|c|c|c|c|c|c|}
\hline Faith & ECOSOC (2000) $1,5,7$ & ECOSOC \& DPI (2003) $2,5,7$ & ECOSOC (2008) $)^{3,5,7}$ & ECOSOC (2012) $4,5,7$ & UNFCCC (2019) ${ }^{5,7}$ \\
\hline Bahá'í & $0 \%$ & $1 \%$ & $0 \%$ & $0.3 \%$ & $4 \%$ \\
\hline Brahma Kumaris & $0 \%$ & $0 \%$ & $0 \%$ & $0 \%$ & $2 \%$ \\
\hline Buddhism & $0 \%$ & $4 \%$ & $4 \%$ & $4 \%$ & $4 \%$ \\
\hline Christian & $61 \%$ & $57 \%$ & $58 \%$ & $60 \%$ & $82 \%$ \\
\hline Daoism/Taoism & $0 \%$ & $0 \%$ & $0 \%$ & $0 \%$ & $0 \%$ \\
\hline Hinduism & $0 \%$ & $0.4 \%$ & $1 \%$ & $3 \%$ & $0 \%$ \\
\hline Interfaith/multifaith & $8 \%$ & $5 \%$ & $3 \%$ & $6 \%$ & $7 \%$ \\
\hline Indigenous spiritual & $0 \%$ & $0 \%$ & $0 \%$ & $0 \%$ & $2 \%$ \\
\hline Islam & $15 \%$ & $12 \%$ & $16 \%$ & $13 \%$ & $0 \%$ \\
\hline Jainism & $0 \%$ & $0.4 \%$ & $0 \%$ & $1 \%$ & $0 \%$ \\
\hline Judaism & $7 \%$ & $11 \%$ & $7 \%$ & $7 \%$ & $0 \%$ \\
\hline $\begin{array}{l}\text { "Other" } 6 \text { \& } \\
\text { "Spiritual" } 6\end{array}$ & $9 \%$ & $9 \%$ & $10 \%$ & $7 \%$ & $\mathrm{~N} / \mathrm{A}$ \\
\hline Shintoism & $0 \%$ & $0 \%$ & $0 \%$ & $0 \%$ & $0 \%$ \\
\hline Sikhism & $0 \%$ & $0 \%$ & $0 \%$ & $0 \%$ & $0 \%$ \\
\hline Zoroastrianism & $0 \%$ & $0 \%$ & $0 \%$ & $0 \%$ & $0 \%$ \\
\hline
\end{tabular}

${ }^{1}$ Source: [24]; ${ }^{2}$ Source: [22]; ${ }^{3}$ Source: [23]; ${ }^{4}$ Source: [21]; ${ }^{5}$ Percentages may not total to 100 due to rounding; 6 "Other" and "spiritual" are other researchers' terms that may include other religions listed by name here; ${ }^{7}$ In order to provide comparable data-because some of the prior studies reported whole numbers and others reported numbers to one or two decimal places-all numerals in Table 6 are whole numbers, with the exception of those less than 0.5 percent, since they would round to zero.

In 2003, Julia Berger studied participation of religious NGOs at the ECOSOC and the DPI. Using a combination of a survey and her own interpretation of whether or not an NGO was religious based on its website, she found 2,060 ECOSOC-accredited NGOs, of which she identified 175, or about 8.5 percent, as religious. Additionally, she found 1,460 DPI-accredited NGOs, of which she identified 184, or about 13 percent, as religious. Importantly, that does not mean she found 359 different religious NGOs, as some of the NGOs accredited by the ECOSOC may have been accredited by DPI as well. Between the ECOSOC and the DPI, Berger compiled a sample of 263 religious NGOs, of which she found that about 57 percent were Christian, about 12 percent Islamic, about 11 percent Jewish, about 9 percent spiritual ${ }^{\mathrm{xx}}$, about 5 percent as multireligious or interfaith/multifaith, about 4 percent as Buddhist, about 1 percent as Bahá'í, just under half a percent as Hindu, and just under half a percent as Jain [22].

In 2010, using data likely ${ }^{x x x i i}$ from 2008, Marie Juul Petersen found 3,183 ECOSOCaccredited NGOs, of which she identified 320, or about 10 percent, as religious. Of those 320, Juul Petersen found that about 58 percent were Christian, about 16 percent Islamic, about 8 percent an undefined "spiritual," about 7 percent Jewish, about 4 percent Buddhist, 
about 3 percent interfaith/multifaith, about 1 percent Hindu and a combined 2 percent for all other faith traditions [23].

Using 2009 data of 3,275 ECOSOC-accredited NGOs, Sophie-Hélène Trigeaud worked with a team that used a keyword search supplemented by a manual scan to identify 239 religious NGOs, of which they classified 62 percent as Christian, 14 percent as Islamic, 8 percent as of Asian traditions (including Buddhism and Hinduism), 7 percent as Jewish, 3 percent as interfaith, and 7 percent as "other" [98]. However, I have excluded their results from Tables 5 and 6 because, as shown by Table 5, the methodology of Trigeaud's team likely led to an undercount by about 100 religious NGOs ${ }^{\mathrm{xx} x i i i}$.

Lastly, Beinlich and Braungart, looking for both overt and non-overt religiosity, found that in 2012 the ECOSOC accredited 3,937 NGOs, of which 339, or about 9 percent, were found to be religious. Of those ECOSOC-accredited religious groups, they found that about 60 percent were Christian, about 13 percent Islamic, about 7 percent Jewish, about 6 percent multireligious or interfaith/multifaith, about 4 percent Buddhist, about 3 percent Hindu, about 1 percent Jain, less than half a percent Bahá'í, and around a combined 7 percent for all other faith traditions [21].

Clearly, while the number of religious NGOs consistently constitutes a small percentage of all ECOSOC-accredited NGOs, it does trend upward over time-and the latest numbers indicate that ECOSOC-accredited religious NGOs make up about three times the representation rate as compared to UNFCCC-accredited religious NGOs.

The denominational distribution of religious NGOs accredited by the UNFCCC provides further evidence for how NGO participation in the COP-and in United Nations agencies overall-is dominated by the Global North and its largest religion, Christianity. This may not be surprising given that the United Nations was founded and remains headquartered in the Global North, but it is a dismal fact to those who would like to see civil-society participation at the United Nations become more representative of the global population.

Non-registered NGOs from other faiths may still participate in the COP through partners or possibly under secular-sounding names that precluded their recognition in this study. For example, many prominent religious NGOs, such as Islamic Relief and GreenFaith, are not accredited by the UNFCCC but find other ways for their leadership to secure badges and participate in the COPs. Still, with UNFCCC-accreditation numbers so heavily Christian, the faith balance at the COP is unlikely to change much from a handful of unaccredited non-Christian NGOs that participate in the COP but fall outside this study.

Comparing UNFCCC-accredited religious NGOs to ECOSOC-accredited religious NGOs yields more insights. Whereas Beinlich and Braungart found that Buddhist groups are quite active in peace and reconciliation at the ECOSOC, Islamic groups are quite active in development at the ECOSOC, and Jewish groups are quite active in human rights at the ECOSOC [21], all three major faiths are relatively absent from the UNFCCC, where there are only two accredited Buddhist groups and none from Islam or Judaism.

Indeed, there are more than 500 million Buddhists in the world; yet my research indicates that only about 4 percent of UNFCCC-accredited religious NGOs are Buddhist (matching the 4 percent of ECOSOC-accredited religious NGOs that are Buddhist as found by Beinlich and Braungart [21]).

With more than a billion Hindus in the world and not a single UNFCCC-accredited Hindu group-even less representation than the 3 percent of ECOSOC-accredited Hindu NGOs reported by Beinlich and Braungart [21] — Hinduism is greatly and mysteriously under-represented at the COP.

While Beinlich and Braungart found that 13 percent of ECOSOC-accredited religious NGOs were Islamic [21], there are no UNFCCC-accredited Islamic groups, although recently Islamic Relief has been sending representatives to the COP $[99,100]$ under other groups' accreditations. Still, with nearly two billion Muslims in the world, Islam is greatly and perplexingly underrepresented at the COP. 
Like the Brahma Kumaris, Jewish groups tend to have a disproportionate involvement in U.N. agencies. Beinlich and Braungart found that 7 percent of ECOSOC-accredited religious NGOs were Jewish [21]. In the UNFCCC, Jewish groups make up zero percent of the religious NGOs, because there is not a single one accredited. Given that there are only an estimated 15 million Jews in the world, zero may seem like it is closer to proportional representation, but actually in terms of proportional representation one might expect one Jewish group for about every 500 groups, or at least four Jewish groups in the 2,222 UNFCCC-accredited NGOs. Instead there are none. That does not mean that there are no Jews involved in the faith circles at the $\mathrm{COP}$-for example, although I registered to attend COP 22 in Marrakech, Morocco, and COP 23, hosted by the Republic of Fiji in Bonn, Germany, under my academic institution's UNFCCC accreditation, I represented the Jewish-environmental nonprofit Aytzim: Ecological Judaism at meetings of the Interfaith Liaison Committee at both COPs ${ }^{\text {xxxiv }}$. Although Aytzim is not accredited (due to lack of sufficient funds), it intermittently has been sending representatives to COPs under the auspices of other organizations since COP 15 . Nonetheless, since there are no UNFCCCaccredited Jewish organizations, there are very few Jewish NGOs participating in the COPs. During my week at COP 22, I and Rabbi Yonatan Neril of Israel's Interfaith Center for Sustainable Development were the only Jews at meetings of the Interfaith Liaison Committee, and I was the only one representing a Jewish NGO. And during my week at COP 23, I was the only Jewish NGO representative at interfaith/multifaith events, as well as at meetings of the Interfaith Liaison Committee.

Unlike many religions, Judaism does not have a single international organizing institution, which is not, as some think, because it has an associated nation state [101] but rather because of its millennia-old history of a plurality of thought and a decentralization that began no later than the split of the Jewish kingdom into Judah and Israel circa 1000 BCE and throttled after the destruction of the Second Temple in 70 CE. Since Jewish NGOs need not first gain the blessing of an international hierarchic institution in order to seek accreditation with the UNFCCC, Judaism's decentralized nature should make it easier for Jewish NGOs to participate in the COP. While most Jewish-environmental organizations, such as Aytzim, are reliant on volunteers and may have few financial resources [102], making pursuit of formal UNFCCC accreditation challenging, there are many large NGOssuch as the American Jewish Committee, B'nai B'rith International, Chabad Lubavitch, Hadassah, the European Union of Jewish Students, and the World Union for Progressive Judaism $^{\mathrm{xxx}}$ - who participate in the ECOSOC and who have the resources to become accredited by the UNFCCC and participate in the COP but have chosen not to do so.

Overall, by comparison to religious NGO participation in the ECOSOC, a much smaller percentage of UNFCCC-accredited NGOs are religious in nature. This may be because the environment draws less attention than other issues-such as peace and conflict, development and human rights-among religious NGOs. It also may provide evidence for those who see the values of environmentalism as in opposition to the values of religion [4,103-106]. In other words, it may provide evidence for White's assertion that religion is anti-environmental. Much work has been done, however, showing how White was wrong or that religion has changed, perhaps in response to White's critique or perhaps in response to changing societal values $[16,17,62,63,65,66,81,83,107-110]$. The question then becomes, why has the work being done by religions to demonstrate their environmental bona fides largely not carried over into participation in the COP? The actual motivations for religious NGOs abstaining from participating in the COP is a subject for future study.

While neither Knox, Berger nor Juul Petersen delineated NGOs geographically, Beinlich and Braungart did. They found that of the ECOSOC-accredited religious groups, 44 percent were based in Europe and in other non-American countries that they defined as "Western;" 38 percent were based in the United States; 10 percent were based in "Asia Pacific;" 5 percent were based in Africa; and 3 percent were based in Latin America and the Caribbean [21]. 
Although my study divided geography by continent as opposed to the Western/nonWestern dichotomy employed by Beinlich and Braungart, my study's numbers are similar to theirs and illustrative of the same result: UNFCCC-accredited religious NGOs, like ECOSOC-accredited religious NGOs, are dominated, at least organizationally, by the Global North. Importantly, however, while the UNFCCC and ECOSOC both accredit NGOs for participation in their U.N. work, organizations self-select to apply for accreditation (albeit for many that application may be bureaucratic to the point of being onerous ${ }^{x \times x i}$, and the prospective financial burden of travel to participate in COPs likely dissuades application for many more). My and Beinlich and Braungart's data suggest that religious NGOs are based primarily in the Global North, or that those in the Global North are most likely to pursue U.N. accreditation, or both - even though countries in the Global South, at least since the 1970s, "are more focused than their larger counterparts on participation in international and regional organizations" [111] such as the United Nations. Organizations from the Global North may be lending their accreditations to register individuals from the Global South, but the under-representation of religious NGOs from the Global South is puzzling, particularly given that it is expected that the Global South will bear the worst negative impacts from climate change [112].

One might argue that the reason that non-Christian religions are underrepresented at the COP is because they are dominant in Global South countries that are very homogeneous in terms of religion, to the extent that practitioners of the predominant religion in those countries may not see the need to send a specifically religious group when their country is so synonymous with their religion. For example, Muslims in Somalia-among the least religiously diverse countries in the world [113] — may not see the point in sending a religious group to the $\mathrm{COP}$ if they see all Somali groups as representing Islamic values. There are two issues with this argument: The first is that the majority of the most religiously diverse countries in the world are in the Global South, so that even countries with majority populations of one religion, such as Bhutan (Buddhism) and India (Hinduism) have sizable populations of other religious groups, giving them religious diversity comparable to the United States [113]. The second is that even if religious groups saw NGOs from their country as being inherently religious by virtue of representing their country, it remains the case that secular groups from the Global South are participating in the COP in disproportionately low numbers, as shown in Table 4. For example, of the 2,222 UNFCCC-accredited NGOs in this study, not one is from Somalia ${ }^{x x v i i}$. Alternatively, consider representation from the countries with the largest populations in the European Union and the Global South: Germany (pop. 83 million) has 149 UNFCCC-accredited NGOs, four of which are religious (all Christian); France (pop. 67 million) has 141, two of which are religious (both Christian); mainland China (pop. 1.4 billion) has 35, none of which are religious; and India (pop. 1.37 billion) has 73, two of which are religious (one Brahma Kumaris and one Christian). Clearly there are significant barriers that are leading to lower overall Global South participation in the UNFCCC, and that depresses religious NGO participation from those countries as well-likely partially explaining the absence of UNFCCC-accredited groups from religions such as Hinduism and Islam that are more common in the Global South than the Global North. But most of the UNFCCC-accredited religious NGOs from the Global South are Christian.

Another possible explanation for the absence of religious groups from the Global South is because the domination of the UNFCCC by colonial powers and their primary religion, Christianity, reverberates with the "marriage of Christianity and empire" [114] that has subsumed and suffocated native peoples around the world. The coloniality of Christian oppression still affects inter-religious discourse today $[115,116]$, perhaps particu-

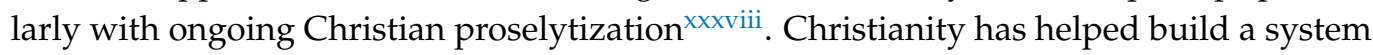
of othering xxxix [117], in this case a system where there is Christianity and then there are all the other-isms, frequently as defined from a Christian perspective [118]. Subsequently, a system dominated by Christianity and the Global North may not be seen as a friendly and 
welcoming place to people in the Global South because of historical and ongoing abuses of power by colonial nations and peoples.

Similarly, groups in the Global South may feel that the Global North does not take them seriously, so why should they bother participating? Groups in the Global South may be less involved because they (rightly) see the climate crisis as the Global North's fault and therefore responsibility [119]. Finally, the travel cost of participating in the COP may be too great a barrier for many groups in the Global South.

It may be the case that religious NGOs at the COP are disproportionately from the Global North because COPs themselves are most commonly hosted in the Global North. As shown in Table 7 and listed in Appendix C, the majority of COPs are held in the Global North - with Europe alone hosting more than half of all COPs-and in part because of unsuccessful efforts to hold COPs in Fiji, Brazil and Chile, the trend has worsened over the past 10 years, during which time Europe has been scheduled to host two-thirds of COPs. To some degree, COP locations are self-selected by host countries who apply to host the conference [120]. However, the UNFCCC selects from the applications, and it does not announce runners up or even how much competition there is for hosting the COP. It also is unclear to what extent if any the UNFCCC recruits countries to host the COP, but deemphasizing Europe and incentivizing more countries in the Global South to host the COP reasonably would yield greater NGO participation from the Global South. Still, no matter the reason for the under-representation of the Global South at the COP, the effect is that the COP may appear to be "an exclusive space bent on reinforcing the capitalist colonial heteropatriarchal norms and systems at the root of [the] climate crisis" [121].

Table 7. Geographic distribution of UNFCCC COPs through 2021.

\begin{tabular}{|c|c|c|c|c|}
\hline Continent & $\begin{array}{c}\text { Total COPs } \\
(2012-2021)\end{array}$ & $\begin{array}{l}\text { Percentage of Total } \\
(2012-2021)\end{array}$ & $\begin{array}{c}\text { Total COPs } \\
(1995-2021)^{2,3,4}\end{array}$ & $\begin{array}{l}\text { Percentage of Total } \\
\quad(1995-2021)\end{array}$ \\
\hline Africa & 1 & $11.11 \%$ & 4 & $15.38 \%$ \\
\hline Antarctica & 0 & $0 \%$ & 0 & $0 \%$ \\
\hline Asia & 1 & $11.11 \%$ & 4 & $15.38 \%$ \\
\hline Australia \& Oceania & 0 & $0 \%$ & 0 & $0 \%$ \\
\hline Europe & 6 & $66.67 \%$ & 14 & $53.85 \%$ \\
\hline North America & 0 & $0 \%$ & 1 & $3.85 \%$ \\
\hline South America & 1 & $11.11 \%$ & 3 & $11.54 \%$ \\
\hline Total & 9 & $100 \%$ & 26 & $100 \%$ \\
\hline
\end{tabular}

\footnotetext{
${ }^{1}$ Source: [122]; ${ }^{2}$ Source: [122-124]; ${ }^{3}$ COP 23 officially was hosted by the Republic of Fiji but was held in Bonn, Germany; COP 25 originally was scheduled to be held in Brazil but after Jair Bolsonaro came to power in Brazil, he withdrew his country's offer to host the COP, which was moved to Chile before being moved again to Madrid, Spain, after mass street protests against inequality in Chile; and COP 26 originally was scheduled to be held in November 2020 before being rescheduled for November 2021 because of the coronavirus pandemic, which may cause its rescheduling yet again; ${ }^{4}$ Because countries did not reach an agreement by the scheduled conclusion of COP 6 in The Hague, Netherlands, the conference was paused and officially resumed the next year in Bonn; each part of COP 6 counts here as one half of a COP, with both halves hosted in Europe.
}

While Beinlich and Braungart speculated that the freedom of religious expression found in much of the Global North may explain why most ECOSOC-accredited religious NGOs are based there [21], my findings show that UNFCCC-accredited NGOs, religious or secular, are both nearly monopolized by the Global North-meaning that religious NGOs are not based in the Global North because of greater religious freedom, but rather that they likely are based in the Global North because they are NGOs involved in the UNFCCC.

Even though North America generally has a more religious population than Europethe percentage of people who say that religion is very important to their lives is much higher in the most populous North American countries (United States: 53 percent; Mexico: 45 percent; Canada: 27 percent) than it is in the most populous European countries (Germany: 10 percent; France: 11 percent; United Kingdom: 10 percent) [125]—my and Beinlich and Braungart's studies find that European NGOs make up the largest geographic group of UN-accredited NGOs. It may be because Europeans are more likely than Americans to want to participate in international political institutions such as the United Nations. Per- 
haps it may indicate that religious participation in a U.N. system is less driven by religious ideology as it is by the secular values of a region. In other words, there may be more religious groups participating from less-religious Europe than from the more-religious North America because of the former's European outlook as opposed to its religious mores. Or it may simply be because "most Americans have no interest in imposing their faith on others and, with the exception of policy toward Israel, religion has little bearing on how they think about international affairs" [126] —although Americans do seem comfortable utilizing religion to promote "religious freedom, tolerance, and interfaith dialogue" [127], sometimes even to the arguable detriment of other populations [127-129], a trend manifested most plainly during the administration of former U.S. Pres. Donald Trump [128,129].

Especially in countries like the United States, however, religious belief seems to affect (or at least correlate with) one's belief in climate change. Although there is variance both between faiths and between faith sects, adherence to Buddhism and Judaism, as well as being a Protestant who is Black, seems to lead to higher levels of belief in climate science than the general population. Conversely, membership in many Christian sects, particularly evangelical Protestantism and non-Hispanic Catholicism, seems negatively associated with interest and belief in climate science $[66,103,130,131]$. Even as the most religious are unlikely to see a conflict between religion and other forms of science, religious Christians still appear to have less faith in climate science than the general population [130]. Furthermore, Christians-and Catholics in particular, since even though acceptance of climate change among the religious seems to have increased, if only in a nuanced way, after Laudato Si [132,133], the papal text may have been more impactful for non-Catholics than Catholics-indicate low trust in what their clergy say about climate change [134]. The dominance of Christian NGOs amongst religious NGOs at the COP points to a potential climate disconnect between religious leadership and those in the pews. Clearly, religious adherents could do better at encouraging their NGOs to participate in the UNFCCC. That they do not may help explain why religion has not fully utilized its potential as a leverage point for climate action [2].

Lastly, part of the blame for the religious NGOs' lack of participation in the COP rests with the United Nations itself: The UNFCCC could do better at proactively reaching out to religious NGOs. And the United Nations inadvertently may be making applying to participate in the UNFCCC more onerous by requiring an overabundance of paperwork from applicants as well as separate accreditation for different U.N. bodies, thereby depressing civil-society participation in niche U.N. processes such as the UNFCCC.

\section{Conclusions}

In the last decade, the number of religious NGOs that participate in the COP has increased dramatically (see Table 5) - and those groups, and the World Council of Churches in particular [26], deserve plaudits-however, even after the growth, religious NGOs consist of a mere 3 percent of UNFCCC-accredited NGOs and about 4 percent of those registered to attend the COP. Although the scope of individual religiosity varies greatly by region, the vast majority of people on Earth have a religious affiliation [135]. Yet religious institutions - particularly those of Daoism/Taoism, Hinduism, Islam, Jainism, Judaism, Shintoism, Sikhism and Zoroastrianism, whose combined adherents make up almost half of the world's population [135] - largely have been absent from the world's preeminent political meetings that are attempting to address the climate emergency, arguably the world's most pressing problem. While their absence may be an outcome of the preeminence of the Global North at the UNFCCC - reflecting the coloniality of global-governance systems-and a result of insufficient efforts by the UNFCCC to engage religious groups, the bureaucratic burden of applying for accreditation, and the cost of participating in COPs, their absence also may reflect the world's ambivalence toward enacting a climate solution, which in turn may be a cause for the ongoing crisis: In a world dominated by religion, what faith can we have in a widely adopted climate cure without the support of religious institutions? 
Alternatively, if world governments are able to overcome the climate silence of religious institutions to successfully address the climate crisis through major efforts and significant sacrifice, despite a lack of religious engagement, will religion become less relevant in adherents' lives? Surely it will not be enough simply for religious organizations to participate in COPs-in the same way that it is not enough for the International Association of Oil and Gas Producers to do so-they must seriously devote themselves to urgently addressing the climate crisis. King warned that "[i]f the church does not recapture its prophetic zeal, it will become an irrelevant social club without moral or spiritual authority" [85]. King may have been referring to Christianity, but his critique may be applicable to most, if not all, religions today. If not acting for the preservation of humanity, religious NGOs should at the very least be acting significantly on climate change for the preservation of religion itself.

In the biblical Book of Esther, the prophet Mordechai offers the following advice to his cousin, Queen Esther, as she dithers over whether or not she, at possible personal peril, should use her power to address the dire emergency being faced by her people. "[I]f you keep silent in this crisis, relief and deliverance will come ... from another quarter," Mordechai says. "And who knows, perhaps you have attained to royal position for just such a crisis" (Esther 4:14). Today one might reasonably question the purpose and integrity of religion if it does not use its royal position to sufficiently address the failing of modernity as well as moral and ethical responsibility that has led to the climate crisis, an existential threat to all humanity. Perhaps religion and its ethics have even been developed, at least in part, to help humanity address just such a crisis.

Although unevenly distributed and unfettered economic growth combined with unsustainable consumption and globally uneven power relationships-all embodied by actions of the Global North - may be most responsible for our entry into this crisis, and even though it certainly is not the responsibility of those who did not make the mess to clean it up, our continued thriving as a species, and likely our very survival, nonetheless may be contingent on all of the religious spiritualities of the world collaborating on a solution leading to a successful sustainability transition. After all, as environmental issues have proven to be potent catalysts for peacemaking [136-138], the climate crisis does not simply represent an existential challenge for humanity, it also offers a possibly unprecedented opportunity for cooperation and peacemaking between religions and peoples. More religious groups would be wise to heed the call.

Funding: The author (ORCID 0000-0001-6062-6628) has been supported in part by an IGERT-SUN (Solar Utilization Network) fellowship funded by the National Science Foundation (Award 1144616). Travel support to COP 22 was provided through the ROI Community by the Charles and Lynn Schusterman Family Philanthropies; travel support to COP 23 was provided by the Center for Jewish Studies at Arizona State University and the Rob and Melani Walton Sustainability Solutions Initiatives at Arizona State University; travel support to meetings of the "Religion and Environmental Change" workshop, at which an early draft of this paper was presented for comment, was provided by the Urban Green Religions project at the University of Basel through funding from the Swiss National Science Foundation.

Institutional Review Board Statement: Not applicable.

Informed Consent Statement: Not applicable.

Data Availability Statement: The data that support the findings of this study were derived from the following resources available in the public domain: unfccc.int/process/parties-non-partystakeholders/non-party-stakeholders/admitted-ngos/list-of-admitted-ngos (accessed on 1 May 2019); and unfccc.int/sites/default/files/resource/PLOP.pdf (accessed on 1 May 2019).

Acknowledgments: The author is grateful for the encouragement of Evan Berry and Randolph Haluza-DeLay, the inspiration of Paul Hirt, Orr Karassin and Alon Tal, and the feedback of his fellow participants in the University of Basel's "Religion and Environmental Change" workshop-Irène Becci, Carrie B. Dohe, Katharina Glaab, Jiska Gojowczyk, Alexandre Grandjean, Lior Herman, Sofiah Jamil, Stéphanie Majerus, Salomé Okoekpen and Vera Schaffer-led by Jens Köhrsen, Julia Blanc 
and Fabian Huber. He also thanks the editors and anonymous reviewers of Sci for their suggestions and assistance, and all others who have helped and encouraged his learning over his academic and professional career.

Conflicts of Interest: The author declares no conflict of interest. The funders had no role in the design of the study; in the collection, analyses, or interpretation of data; in the writing of the manuscript; or in the decision to publish the results.

\begin{abstract}
Abbreviations
CMP: Conference of the Parties Serving as the Meeting of the Parties to the Kyoto Protocol; CMA: Conference of the Parties serving as the Meeting of the Parties to the Paris Agreement; COP: Conference of Parties; DPI: United Nations Department of Public Information; ECOSOC: United Nations Economic and Social Council; IPCC: Intergovernmental Panel on Climate Change; NGO: nongovernmental organization; UNFCCC: United Nations Framework Convention on Climate Change.
\end{abstract}

\title{
Appendix A. UNFCCC-Accredited Religious NGOs as of May 2019 (Including Institutions of Higher Learning), with Naming Convention According to the UNFCCC
}

ACT Alliance-Action by Churches Together (ACT Alliance)

All Africa Conference of Churches (AACC)

Brahma Kumaris World Spiritual University (BKWSU)

Bread for the World (BfdW)

Buddhist Tzu Chi Foundation

Care of Creation, Inc.

Caritas Internationalis (CI)

Catholic Institute for International Relations (CIIR)

Catholic Relief Services-United States Conference of Catholic Bishops (CRS)

Catholic Rural Youth Movement Germany e.V. (KLJB)

Catholic Youth Network for Environmental Sustainability in Africa (CYNESA)

Christian Aid (CA)

Christian Commission for Development in Bangladesh (CCDB)

Church of the Brethren (COB)

Church's Auxiliary for Social Action (CASA)

Comité Catholique contre la Faim et pour le Développement 13 Terre solidaire (CCFD-Terre Solidaire)

Congregation of Our Lady of Mount Carmel (Carmelite NGO)

Cooperation Internationale pour le Développement et la Solidarité (CIDSE)

Dharma Drum Mountain Buddhist Association (DDMBA)

Diakonia

Domestic and Foreign Missionary Society of the Protestant Episcopal Church in the USA Economic Justice Network of the Fellowship of Christian Councils of Southern Africa (EJN)

Ecumenical Advocacy Alliance (EAA)

Evangelical Environmental Network (EEN)

Evangelical Lutheran Church in America (ELCA)

Evangelist Professional Training School

Faith Association of the Rehabilitation of Street Children and Orphans (FARSO)

Finn Church Aid Foundation (FCA)

Franciscans International (FI)

Friends World Committee for Consultation

Hong Kong Baptist University (HKBU)

Indigenous Education Network of Turtle Island (IENTI/IEN)

Interchurch Organization for Development Cooperation (ICCO)

Jeunesse Étudiante Catholique Internationale (IYCS-JECI)

Lutheran World Federation (LWF)

Maryknoll Fathers and Brothers (CFMSA)

Maryknoll Sisters of Saint Dominic Inc.

Mercy International Association (MIA) 
MISEREOR, German Catholic Bishops' Organisation for Development Cooperation (MISEREOR) National Spiritual Assembly of the Baha'is of the United States (Baha'i International Community) Organisation des Laics Engages du Sacré Coeur pour le Developpement de Kimbondo (OLESDK) Presbyterian Church (U.S.A.)

Quaker Earthcare Witness (QEW)

Sjoham Baabaji Mission

Society of Catholic Medical Missionaries (SCMM)

Southern African Faith Communities' Environment Institute (SAFCEI)

Tearfund

Texas Impact Education Fund doing business as the Texas Interfaith Center for Public Policy (TICPP)

The Interfaith Center for Sustainable Development (ICSD)

Unitarian Universalist Association (UUA)

United Church of Canada

United Methodist Church-General Board of Church and Society (UMC-GBCS)

World Alliance of Young Men's Christian Associations (YMCA)

World Conference of Religions for Peace (WCRP)

World Council of Churches (WCC)

World Vision International (WVI)

World Young Women's Christian Association (World YWCA)

\section{Appendix B. Religious NGOs at COP 24, with Naming Convention According to the Observer-Registration Forms of Accredited NGOs}

ACT Alliance-Action by Churches Together

Brahma Kumaris World Spiritual University

Bread for the World

Buddhist Tzu Chi Foundation

Care of Creation

Caritas Internationalis

Catholic Fund for Overseas Development

Catholic Relief Services-United States Conference of Catholic Bishops

Catholic Rural Youth Movement Germany

Catholic Youth Network for Environmental Sustainability in Africa

Christian Aid

Christian Commission for Development in Bangladesh

Church of Sweden

Church's Auxiliary for Social Action

Comité Catholique contre la Faim et pour le Développement - Terre solidaire

Congregation of Our Lady of Mount Carmel

Cooperation internationale pour le développement et la solidarité

DescriptionDanChurchAid

Dharma Drum Mountain Buddhist Association

Diakonia

Domestic and Foreign Missionary Society of the Protestant Episcopal Church in the USA

Dominicans for Justice and Peace

Ecological Christian Organisation

Ecumenical Advocacy Alliance

Ecumenical Youth Council in Europe

Evangelical Lutheran Church in America

Faith Association of the Rehabilitation of Street Children and Orphans

Fastenopfer-Swiss Catholic Lenten Fund

Friends World Committee for Consultation

GreenFaith

Indigenous Education Network of Turtle Island

Inter-Religious Climate and Ecology Network

Interfaith Power and Light

Jeunesse Étudiante Catholique Internationale

Lutheran World Federation

Maryknoll Fathers and Brothers

Maryknoll Sisters of Saint Dominic 
Mercy International Association

Micah Zambia

MISEREOR, German Catholic Bishops' Organisation for Development Cooperation

Norwegian Church Aid

Norwegian Interfaith Climate Network

Organisation des Laics Engages du Sacré Coeur pour le Developpement de Kimbondo

Pacific Conference of Churches

Presbyterian Church (U.S.A.)

Quaker Earthcare Witness

Secours Catholique

Tearfund

Texas Impact Education Fund doing business as the Texas Interfaith Center for Public Policy

The Interfaith Center for Sustainable Development

Unitarian Universalist Association

United Church of Canada

United Methodist Church-General Board of Church and Society

World Alliance of Young Men's Christian Associations

World Conference of Religions for Peace

World Council of Churches

World Evangelical Alliance

World Vision International

\section{Appendix C. UNFCCC COPs}

COP 1: Berlin, Germany, 28 March-7 April 1995

COP 2: Geneva, Switzerland, 8-19 July 1996

COP 3: Kyoto, Japan, 1-10 December 1997

COP 4: Buenos Aires, Argentina, 2-13 November 1998

COP 5: Bonn, Germany, 25 October-5 November 1999

COP 6 (part 1): The Hague, Netherlands, 13-24 November 2000

COP 6 (part 2): Bonn, Germany, 16-27 July 2001

COP 7: Marrakech, Morocco, 29 October-9 November 2001

COP 8: New Delhi, India, 23 October-1 November 2002

COP 9: Milan, Italy, 1-12 December 2003

COP 10: Buenos Aires, Argentina, 6-17 December 2004

COP 11: Montreal, Canada, 28 November-9 December 2005

COP 12: Nairobi, Kenya, 6-17 November 2006

COP 13: Bali, Indonesia, 3-17 December 2007

COP 14: Poznań, Poland, 1-12 December 2008

COP 15: Copenhagen, Denmark, 7-18 December 2009

COP 16: Cancún, Mexico, 28 November-10 December 2010

COP 17: Durban, South Africa, 28 November-9 December 2011

COP 18: Doha, Qatar, 26 November-7 December 2012

COP 19: Warsaw, Poland, 11-23 November 2013

COP 20: Lima, Peru, 1-12 December 2013

COP 21: Paris, France, 30 November-12 December 2015

COP 22: Marrakech, Morocco, 7-18 November 2016

COP 23: Bonn, Germany, 6-17 November 2017

COP 24: Katowice, Poland, 3-14 December 2018

COP 25: Madrid, Spain, 2-13 December 2019

COP 26: Glasgow, U.K., scheduled for 1-12 November 2021

\section{Notes}

The COP is sometimes stylized as "CoP."

There also are other COPs outside of the UNFCCC. For example, other U.N. treaties-such as the Convention on Biological Diversity, the Convention on the Conservation of Migratory Species of Wild Animals, and the Convention on International Trade in Endangered Species of Wild Fauna and Flora-have their own COPs that are independent from each other and from the UNFCCC's COP. In this paper, the COP refers solely to the UNFCCC's COP. 
iii The COP also serves as the conference for other subsequent UNFCCC-related agreements, such as the CMP-the Conference of the Parties Serving as the Meeting of the Parties to the Kyoto Protocol-and the CMA-the Conference of the Parties Serving as the Meeting of the Parties to the Paris Agreement. For example, COP 24 also was CMP 15 and CMA 2. In this paper, the COP refers to the entire conference, complete with its concurrent meetings such as CMPs and CMAs.

iv The COP and the UNFCCC operate independently but in concert with the U.N. Intergovernmental Panel on Climate Change, or IPCC. Basically, the IPCC conducts research that is utilized by the UNFCCC, which is both the name of the international climate-change agreement endorsed by nations as well as the name of the U.N. secretariat, or agency, that assists the work of those who signed the agreement, organizes negotiation meetings and, together with countries, hosts annual conferences, or COPs, of the parties to the convention, or those who signed the UNFCCC treaty. The COP, in turn, serves as the governing body for the UNFCCC.

$\mathrm{v} \quad$ White also briefly praised Buddhism as the mirrored opposite of Christianity and made passing references to Judaism and Islam, but only in reference to Christianity.

vi One of six major U.N. organs, ECOSOC consists of 54 rotating member states tasked with addressing social and economic policy. It operates independently from the COP and the UNFCCC.

vii In the time between COPs, the UNFCCC organizes one (and sometimes none, sometimes two) significantly smaller climatechange conference that hosts negotiations and committee meetings for UNFCCC groups such as the Ad Hoc Working Group on the Durban Platform for Enhanced Action, the Ad Hoc Working Group on the Paris Agreement, the Subsidiary Body for Scientific and Technological Advice, and the Subsidiary Body for Implementation. These groups do important work, of course, but whether the UNFCCC holds meetings once, twice or even thrice annually, the point is the same: Picking up on negotiations six months later or a year later-over what has so far been a quarter century-simply is not adequately addressing the urgent action demanded by the climate crisis.

viii The COP talks of immediacy but actually has the fierce urgency of a sloth-which is simply reflective of (rather than the cause of) global inaction on climate change. It seems that many countries are more interested in filibustering to delay global action-not necessarily out of climate denial as much as out of climate avoidance, arguably in the interest of protecting the short-term monetary interests of those who benefit from the status quo. Those countries officially may recognize climate change as an existential threat but they do not seem particularly interested in taking the significant and urgent action that an existential threat demands.

ix That dovetails with those who espouse inaction on other threats, both preexisting (such as racism and economic inequality) and relatively new (such as the novel coronavirus [SARS-CoV-2, the virus that causes the disease COVID-19] and unsustainable consumption that pushes the limits of the Earth's carrying capacity).

$x \quad$ The bumbling, slapstick policemen who cannot get the job done in the Keystone Film Company's early 20th-century silent films.

xi Furthermore, it is then through becoming better humans (often through religious practice of universalist prosocial values) that we can ascend spiritually, reach enlightenment and/or serve the Divine.

xii These nine constituency groups were borrowed from those delineated in Agenda 21 as adopted in Rio de Janeiro at the 1992 Earth Summit, officially known as the first U.N. Conference on Environment and Development, at which the UNFCCC was born.

xiii Due to the UNFCCC-accreditation timeline, the UNFCCC-accreditation list as of 1 May is the same as the list of NGOs that were eligible to register representatives at the previous year's COP. New applicants from any year are not informed of a decision by UNFCCC until a year or two later, typically depending upon when they apply in relation to 31 August. For example, an NGO that applied to the UNFCCC for accreditation on 31 August 2018 would not have been informed of the UNFCCC's decision until June or July of 2019, and an NGO that applied for accreditation on 1 September 2018 would not have been informed of the UNFCCC's decision until June or July of 2020. In the case of this study, the accreditation list as of 1 May 2019 mirrors the complete list of those organizations that were eligible to register representatives for COP 24 in December 2018.

xiv When an NGO's name was neither clearly secular nor clearly religious, I consulted the NGO's website to determine its classification. For example, the Jwala Trust in Haryana, India, is accredited by the UNFCCC, and I checked its website to confirm that it was indeed the secular Jwala Trust that works in sustainable development and not the Sri Jwala Prayoga Central Trust, a Hindu group with offices in Chennai and Hyderabad, India.

xv A close reading of Brewer, however, reveals a more nuanced stance: When he said that the United States is a Christian nation he noted that it was not officially Christian and that he only meant that it was a country whose populace largely was Christian and whose laws and history had been influenced greatly by Christianity.

xvi It is possible, of course, that an organizational name that may have been overtly religious to its group members may not have seemed overtly religious to me. Furthermore, some ambiguity may be unavoidable: Religious groups on the fringes of Christianity and/or groups whose heritages are in Christianity but whose inclusion in the umbrella of Christianity today would be questionable, (hotly) debatable, or at the very least a source of tension-groups such as Mormons, Quakers (Friends) and Unitarian Universalists-were classified in this study as Christian rather than navigating the rabbit hole of determining at what point sects become fully independent of their roots (as such church-sect typologies have been much 
debated since delineated by sociologists and theologians such as Max Weber and Ernst Troeltsch in the early 20th century); arguably each (or some) of the groups classified in this study as Christian should have been classified as separate religions, and follow-up studies should consider the classification further.

As its name implies, the U.N. Department of Global Communications, formerly the DPI, focuses on communicating the work of the United Nations to the public. It, like ECOSOC, operates independently from the COP and the UNFCCC. As such, I have excluded the study's results from comparisons with previous studies.

xix In response to the hesitancy that representatives from non-sectarian Jewish organizations such as Jewish Women International and the Zionist Organization of America expressed in response to being asked if they were "religious," Berger-who works at the Bahá'í International Community's United Nations Office-mistakenly concluded that the term religious is "complicated by the ambiguous nature of organizations' religious identity" [22]. However it actually was complicated by a misunderstanding of the nuances and intersectionality of Judaism, where the term "religious" is often interpreted as meaning those who are adherents of the religion's Orthodox sects. While Judaism consists of an intersectional combination of religion, culture and ethnicity, Jewish non-sectarian groups typically will not define themselves as religious in the Jewish sense of the word; but they are, as Berger noted, aware that their work is of or pertaining to religion, aka religious-even if they define themselves as "secular" — since in Judaism the terms secular and religious usually refer to where one sees one's place on a fictitious spectrum of different Jewish sects. In this model, sects such as Reform or Reconstructionist are falsely but commonly perceived as unreligious, and certainly perceived as less religious than Orthodox sects, with the latter solely serving as "religious" in the minds of many. This is likely a shared issue with people of other faiths, and it reveals an issue with survey data in that different respondents may have different definitions for selected words. Nonetheless Berger's misunderstanding has been cited and replicated throughout the literature.

xx Jewish National Fund in Israel, alternatively transliterated as Keren Kayemeth LeIsrael and commonly known by the initials KKL-JNF.

xxi Also known as IGOs.

xxii Correspondingly, Russia was classified as European; Egypt was classified as African; Armenia, Azerbaijan, Georgia, Indonesia, Kazakhstan and Turkey were classified as Asian; Caribbean countries were classified as North American; South American countries with island possessions in the Caribbean or Oceania were classified as South American; the United States, which has territories around the world, was classified as North American; and European colonial powers with territories around the world were classified as European. continents instead since the U.N. grouping includes a number of "special case" exclusions, such as Israel and Turkey, and some unintuitive classifications, such as the placement of Cyprus in the Asia-Pacific group.

Although NGOs based in one place can register representatives from another-for example, an NGO based in Switzerland can register a representative from India-an NGO's location remains important as an indicator of where NGO leadership is based. While Chile technically remained the host country of COP 25, the conference itself was hosted entirely in Spain. To what degree the last-minute change of venue affected the makeup of NGO participation is unknown.

Statistical analysis allows for estimation of percentages of a population based on a sample. This study, however, covers the entire population rather than a sample, so the reported percentages are actual rather than statistically estimated. Although its adherents only number in the hundreds of thousands, Zoroastrianism is included here because of its age and historic influence.

xxviii The UNFCCC document used to build this study's database erroneously reports the total as 22,771. Not surprisingly, none is based in Antarctica, although it is home to several thousand people housed at nearly 100 seasonal and permanent research stations.

Fossil-fuel interests are permitted to become accredited by the UNFCCC; UNFCCC-accredited NGOs need not be nonprofits, need not be seriously committed to a drawdown of fossil fuels, and they self-select for consideration of accreditation.

xxxi Berger classified Brahma Kumaris as spiritual.

xxxii Juul Petersen did not provide the year for her data. Given Trigeaud's search of 3,275 ECOSOC-accredited NGOs in 2009, it is likely that Juul Petersen's findings of 3,183 ECOSOC-accredited NGOs was from 2008 data.

xxxiii Given that Trigeaud misreported the number of ECOSOC-accredited NGOs found by Juul Petersen as 3,181 instead of 3,183, and given that Trigeaud was reporting findings a half-dozen years after data collection, it also is possible that Trigeaud accidentally misreported her own data. (Perhaps she found 329 but transposed the numbers as 239?)

xxxiv Similarly, at COP 23 I met Gopal Patel, who directs the Hindu-environmental group the Bhumi Project and had attended COP 23 as a representative of GreenFaith and registered under the accreditation of the World Council of Churches. However, neither his nor his group's name is on the UNFCCC's provisional registration list for COP 24, whose attendees were the focus of this study. The lack of formal accreditation for some religious groups makes their participation inconsistent from one year 
to the next, and always dependent upon the availability of extra registration slots held by accredited organizations-as well as relationships with those groups in order to benefit from their support.

xxxv The international arm of the Liberal, Progressive, Reconstructionist and Reform sects of Judaism.

xxxvi Applications require a slew of documents, including copies of governmental certificate of incorporation; certificate of nonprofit status; organizational bylaws; documents that establish what happens to an organization's assets in case of dissolution; financial statement for the most recent accounting year; lists of the names of donors and other sources of funding for the past two years; and organizational annual reports for the past two years. Lacking any required document nullifies one's application, which will only be considered for accreditation once annually.

xxxvii Although Somalia has no UNFCCC-accredited NGOs, the country still sends representatives from other segments of society, such as the government, to COPs.

xxxviii Christians are not the only proselytizers, but judging by total numbers—Christianity is the largest religion in the world—-they have been the most prolific and/or successful proselytizers.

xxxix In that sense and despite my non-Christian background, ancestry and education-and although Judaism's self-definition of religion is quite different from Christianity's, particularly in how the Jewish marriage of faith and tribalism more closely hews to the spirituality of other indigenous peoples-this paper nonetheless unintentionally may play into the colonial history of othering through the act of classification by using Beinlich and Braungart's definition of religious groups, which is arguably a Christian definition.

\section{References}

1. Cabré, M.M. Issue-Linkages to Climate Change Measured through NGO Participation in the UNFCCC. Glob. Environ. Politics 2011, 11, 10-22. [CrossRef]

2. Caniglia, B.S.; Brulle, R.J.; Szasz, A. Civil Society, Social Movements, and Climate Change. In Climate Change and Society: Sociological Perspectives; Dunlap, R.E., Brulle, R.J., Eds.; Oxford University Press: Oxford, UK, 2015; pp. $235-268$.

3. Francis. Encyclical Letter: Laudato Si of the Holy Father Francis on Care for Our Common Home; The Vatican: Rome, Italy, 2015; pp. 1-184.

4. White, L., Jr. The Historical Roots of Our Ecologic Crisis. Science 1967, 155, 1203-1207. [CrossRef] [PubMed]

5. Wallerstein, I. Where Should Sociologists Be Heading? Contemp. Sociol. 2000, 29, 306-308. [CrossRef]

6. Cayton, A.R.L. Insufficient Woe: Sense and Sensibility in Writing Nineteenth-Century History. Rev. Am. Hist. 2003, 31, 331-341. [CrossRef]

7. Neethling, T. The Development of Normative Theory in International Relations: Some Practical Implications for Norm-Based and Value-Based Scholarly Inquiry. Koers Bull. Christ. Scholarsh. 2004, 69, 1-25. [CrossRef]

8. Frost, M. Towards a Normative Theory of International Relations: A Critical Analysis of the Philosophical and Methodological Assumptions in the Discipline with Proposals towards a Substantive Normative Theory; Cambridge University Press: Cambridge, UK, 1986.

9. Dyer, H. Moral Order/World Order: The Role of Normative Theory in the Study of International Relations; MacMillan Press: London, UK, 1997.

10. Dyer, H.C. Normative Theory and International Relations. In The Study of International Relations: The State of the Art; Dyer, H.C., Mangasarian, L., Eds.; Palgrave Macmillan: New York, NY, USA, 1989; pp. 172-185.

11. Cochran, M. Normative Theory in International Relations: A Pragmatic Approach; Cambridge University Press: Cambridge, UK, 2004.

12. Brown, C. Not My Department? Normative Theory and International Relations. Paradigms 1987, 1, 104-113. [CrossRef]

13. Wang, L.-S. Causal Efficacy and the Normative Notion of Sustainability Science. Sustain. Sci. Pract. Policy 2011, 7, 30-40. [CrossRef]

14. Jamieson, Dale. Ethics and the Environment: An Introduction; Cambridge University Press: Cambridge, UK, 2008.

15. Taylor, B.R. Dark Green Religion: Nature, Spirituality and the Planetary Future; University of California Press: Berkeley, CA, USA, 2010; pp. 1-338.

16. Taylor, B.; Van Wieren, G.; Zaleha, B. The Greening of Religion Hypothesis (Part Two): Assessing the Data from Lynn White, Jr., to Pope Francis. J. Study Relig. Nat. Cult. 2016, 10, 306-378. [CrossRef]

17. Taylor, B.; Van Wieren, G.; Zaleha, B.D. Lynn White Jr. and the Greening-of-Religion Hypothesis. Conserv. Biol. 2016, 30, 1000-1009. [CrossRef]

18. LeVasseur, T.; Peterson, A. Religion and Ecological Crisis: The "Lynn White Thesis" at Fifty; Routledge: Abingdon, UK, 2016; pp. 1-214.

19. Næss, A. The Shallow and the Deep, Long-Range Ecology Movement: A Summary. Inquiry 1973, 16, 95-100. [CrossRef]

20. Riley, M.T. The Democratic Roots of Our Ecologic Crisis: Lynn White, Biodemocracy, and the Earth Charter. Zygon 2014, 49, 938-948. [CrossRef]

21. Beinlich, A.-K.; Braungart, C. Religious NGOs at the UN: A Quantitative Overview. In Religious NGOs at the United Nations: Polarizers or Mediators? Baumgart-Ochse, C., Wolf, K.D., Eds.; Routledge: Oxon, UK, 2019; pp. $26-46$.

22. Berger, J. Religious Nongovernmental Organizations: An Exploratory Analysis. Volunt. Int. J. Volunt. Nonprofit Organ. 2003, 14, 15-39. [CrossRef] 
23. Juul Petersen, M. International Religious NGOs at the United Nations: A Study of a Group of Religious Organizations. J. Humanit. Assist. 2010, 17.

24. Knox, G. Religion and Public Policy at the UN; Religion Counts: Downers Grove, IL, USA, 2002; pp. 1-72.

25. Carrette, J. The Paradox of Globalisation: Quakers, Religious NGOs and the United Nations. In Religions in Movement: The Local and the Global in Contemporary Faith Traditions; Hefner, R.W., Hutchinson, J., Mels, S., Timmerman, C., Eds.; Routledge: London, UK, 2013; pp. 47-66.

26. Krantz, D. Climate and Covenant: A Case Study of the Functions, Goals and Tensions of Faith at the 23rd Conference of Parties to the United Nations Framework Convention on Climate Change. In Global Religious Environmental Activism: Emerging Tensions in Earth Stewardship; Köhrsen, J., Blanc, J., Huber, F., Eds.; Routledge: London, UK, Forthcoming.

27. Ehlers, E.; Krafft, T. Earth System Science in the Anthropocene; Springer: Berlin/Heidelberg, Germany, 2006.

28. Steffen, W.; Crutzen, P.J.; McNeill, J.R. The Anthropocene: Are Humans Now Overwhelming the Great Forces of Nature? AMBIO J. Hum. Environ. 2007, 26, 614-621. [CrossRef]

29. Smith, B.D.; Zeder, M.A. The Onset of the Anthropocene. Anthropocene 2013, 4, 8-13. [CrossRef]

30. Haraway, D. Anthropocene, Capitalocene, Plantationocene, Chthulucene: Making Kin. Environ. Humanit. $2015,6,159-165$. [CrossRef]

31. Samways, M. Translocating Fauna to Foreign Lands: Here Comes the Homogenocene. J. Insect Conserv. 1999, 3, 65-66.

32. Chwałczyk, F. Around the Anthropocene in Eighty Names-Considering the Urbanocene Proposition. Sustainability 2020, $12,4458$. [CrossRef]

33. Gore, A. An Inconvenient Truth: The Planetary Emergency of Global Warming and What We Can Do About It; Rodale: New York, NY, USA, 2006.

34. Union of Concerned Scientists. World Scientists' Warning to Humanity; Union of Concerned Scientists: Cambridge, UK, 1992.

35. Ripple, W.J.; Wolf, C.; Newsome, T.M.; Galetti, M.; Alamgir, M.; Crist, E.; Mahmoud, M.I.; Laurance, W.F. 15364 scientist signatories from 184 countries. World Scientists' Warning to Humanity: A Second Notice. BioScience 2017, 67, 1026-1028. [CrossRef]

36. Intergovernmental Panel on Climate Change. Global Warming of $1.5^{\circ}$ C: First Joint Session of Working Groups I, II and III of the IPCC and Accepted by the 48th Session of the IPCC; United Nations: Geneva, Switzerland, 2018.

37. Rockström, J.; Steffen, W.; Noone, K.; Persson, Å.F., III; Stuart, C.; Lambin, E.F.; Lenton, T.M.; Scheffer, M.; Folke, C.; Schellnhuber, H.J.; et al. A Safe Operating Space for Humanity. Nature 2009, 461, 472-475. [CrossRef] [PubMed]

38. Mann, M.E.; Toles, T. The Madhouse Effect: How Climate Change Denial is Threatening Our Planet, Destroying Our Politics, and Driving Us Crazy; Columbia University Press: New York, NY, USA, 2016.

39. Thunberg, G. If World Leaders Choose to Fail Us, My Generation Will Never Forgive Them. The Guardian 23 September 2019. p Opinion. Available online: theguardian.com/commentisfree/2019/sep/23/world-leaders-generation-climate-breakdowngreta-thunberg (accessed on 23 September 2019).

40. Sabherwal, A.; Ballew, M.T.; van der Linden, S.; Gustafson, A.; Goldberg, M.H.; Maibach, E.W.; Kotcher, J.E.; Swim, J.K.; Rosenthal, S.A.; Leiserowitz, A. The Greta Thunberg Effect: Familiarity with Greta Thunberg predicts intentions to engage in climate activism in the United States. J. Appl. Soc. Psychol. 2021, 1-13. [CrossRef]

41. Smith, D. 'Anti-Greta' Teen Activist to Speak at Biggest US Conservatives Conference. The Guardian, 25 February 2020. Available online: theguardian.com/us-news/2020/feb/25/anti-greta-teen-activist-cpac-conference-climate-sceptic (accessed on 15 March 2021).

42. Butler, D.; Eilperin, J. The Anti-Greta: A Conservative Think Tank Takes on the Global Phenomenon. The Washington Post, 24 February 2020; p. A1.

43. Wanliss, J. Resisting the Green Dragon: Dominion, Not Death; Cornwall Alliance for the Stewardship of Creation: Burke, VA, USA, 2010.

44. Schlanger, Z. Dark Money Research: The 'Scientists' Who Support Trump's Choice to Run the EPA are Creationists with Opaque Funding Sources. In Quartz, 18 January ed.; New York, NY, USA, 2017.

45. ThinkProgress. The Oily Operators Behind the Religious Climate Change Disinformation Front Group, Cornwall Alliance. In ThinkProgress, 19 June ed.; 2010. Available online: archive.thinkprogress.org/the-oily-operators-behind-the-religious-climatechange-disinformation-front-group-cornwall-alliance-536175fe5e04/ (accessed on 27 February 2020).

46. Buxton, N. COP 21 Charades: Spin, Lies and Real Hope in Paris. Globalizations 2016, 13, 934-937. [CrossRef]

47. Bortscheller, M.J. Equitable but Ineffective: How the Principle of Common but Differentiated Responsibilities Hobbles the Global Fight against Climate Change. Sustain. Dev. Law Policy 2009, 10, 49.

48. Schenck, L. Climate Change "Crisis"—Struggling for Worldwide Collective Action. Colo. J. Int. Law Policy 2008, $19,319$.

49. Hermwille, L.; Obergassel, W.; Ott, H.E.; Beuermann, C. UNFCCC Before and After Paris—What's Necessary for an Effective Climate Regime? Clim. Policy 2017, 17, 150-170. [CrossRef]

50. Riedy, C.; McGregor, I. Climate Governance is Failing Us: We All Need to Respond. PORTAL J. Multidiscip. Int. Stud. 2011, 8. [CrossRef]

51. Muller, B. Copenhagen 2009: Failure or Final Wake-Up Call for Our Leaders? Oxford Institute for Energy Studies: Oxford, UK, 2010; pp. 1-35.

52. Kutney, G. Carbon Politics and the Failure of the Kyoto Protocol; Routledge: London, UK, 2013. 
53. Parker, C.F.; Karlsson, C.; Hjerpe, M.; Linnér, B.O. Fragmented Climate Change Leadership: Making Sense of the Ambiguous Outcome of COP-15. Environ. Politics 2012, 21, 268-286. [CrossRef]

54. Bodansky, D. The Copenhagen Conference: A Post-Mortem. Am. J. Int. Law 2010, 104, 230-240. [CrossRef]

55. Cadman, T.; Radunsky, K.; Simonelli, A.; Maraseni, T. From Paris to Poland: A Postmortem of the Climate Change Negotiations. Int. J. Soc. Qual. 2018, 8, 27-46. [CrossRef]

56. Boden, T.A.; Marland, G.; Andres, R.J. Global, Regional, and National Fossil-Fuel $\mathrm{CO}_{2}$ Emissions. Available online: osti.gov/dataexplorer/biblio/1389331-global-regional-national-fossil-fuel-co2-emissions (accessed on 23 April 2019).

57. Watson, R.; McCarthy, J.J.; Canziani, P.; Nakicenovic, N.; Hisas, L. The Truth Behind the Climate Pledges; Universal Ecological Fund: Alexandria, VA, USA, 2019; pp. 1-30.

58. Broecker, W.S. Climatic Change: Are We on the Brink of a Pronounced Global Warming? Science 1975, 189, 460-463. [CrossRef]

59. Stevens, W.K. Scientist at Work: Wallace S. Broecker; Iconoclastic Guru of the Climate Debate. The New York Times, 17 March 1998 ; p. F1.

60. Lövbrand, E.; Hjerpe, M.; Linnér, B.-O. Making Climate Governance Global: How UN Climate Summitry Comes to Matter in a Complex Climate Regime. Environ. Politics 2017, 26, 580-599. [CrossRef]

61. Meadows, D. Leverage Points: Places to Intervene in a System. In Thinking in Systems: A Primer; Chelsea Green Publishing: White River Junction, VT, USA, 2008; pp. 145-165.

62. Wisner, B. Untapped Potential of the World's Religious Communities for Disaster Reduction in an Age of Accelerated Climate Change: An Epilogue \& Prologue. Religion 2010, 40, 128-131.

63. Posas, P.J. Roles of Religion and Ethics in Addressing Climate Change. Ethics Sci. Environ. Politics 2007, 2007, 31-49. [CrossRef]

64. Haluza-DeLay, R. Religion and Climate Change: Varieties in Viewpoints and Practices. Wiley Interdiscip. Rev. Clim. Chang. 2014, 5, 261-279. [CrossRef]

65. Schipper, E.L.F. Religion as an Integral Part of Determining and Reducing Climate Change and Disaster Risk: An Agenda for Research. In Climate Change: The Social Science Perspective; Voss, M., Ed.; VS-Verlag: Wiesbaden, Germany, 2010; pp. $377-393$.

66. Morrison, M.; Duncan, R.; Parton, K. Religion Does Matter for Climate Change Attitudes and Behavior. PLoS ONE 2015, 10, e0134868. [CrossRef] [PubMed]

67. Hulme, M. Climate Change and the Significance of Religion. Econ. Political Wkly. 2017, 3, 14-17.

68. Glaab, K. A Climate for Justice? Faith-Based Advocacy on Climate Change at the United Nations. Globalizations 2017, 14, 1110-1124. [CrossRef]

69. Haynes, J. Faith-Based Organizations at the United Nations; Palgrave Macmillan: New York, NY, USA, 2014; pp. 1-180.

70. Glaab, K.; Fuchs, D.; Friederich, J. Religious NGOs at the UNFCCC: A Specific Contribution to Global Climate Politics? In Religious NGOs at the United Nations: Polarizers or Mediators? Baumgart-Ochse, C., Wolf, K.D., Eds.; Routledge: Oxon, UK, 2019; pp. $61-77$.

71. Carrette, J.; Miall, H. Religion, NGOs and the United Nations: Visible and Invisible Actors in Power; Bloomsbury Academic: London, UK; New York, NY, USA, 2017; pp. 1-302.

72. Rivlin, B. Thoughts on Religious NGOs at the UN: A Component of Global Civil Society. In Civil Society in the Information Age; Hajnal, P.I., Ed.; Routledge: London, UK, 2018; pp. 155-174.

73. Habito, R.L.F.; Inaba, K. The Practice of Altruism Caring and Religion in Global Perspective; Cambridge Scholars Press: Newcastle, UK, 2006.

74. Saroglou, V. Religion, Spirituality, and Altruism. APA Handb. Psychol. Relig. Spiritual. 2013, 1, 439-457.

75. Norenzayan, A.; Shariff, A.F. The Origin and Evolution of Religious Prosociality. Science 2008, 322, 58-62. [CrossRef]

76. Norenzayan, A.; Shariff, A.F.; Gervais, W.M.; Willard, A.K.; McNamara, R.A.; Slingerland, E.; Henrich, J. The Cultural Evolution of Prosocial Religions. Behav. Brain Sci. 2016, 39, 1-65. [CrossRef] [PubMed]

77. Shariff, A.F.; Norenzayan, A. God is Watching You: Priming God Concepts Increases Prosocial Behavior in an Anonymous Economic Game. Psychol. Sci. 2007, 18, 803-809. [CrossRef]

78. Shariff, A.F.; Willard, A.K.; Andersen, T.; Norenzayan, A. Religious Priming: A Meta-Analysis with a Focus on Prosociality. Personal. Soc. Psychol. Rev. 2016, 20, 27-48. [CrossRef]

79. Bush, E.L. Measuring Religion in Global Civil Society. Soc. Forces 2007, 85, 1645-1665. [CrossRef]

80. Pierotti, R.; Wildcat, D. Traditional Ecological Knowledge: The Third Alternative (Commentary). Ecol. Appl. 2000, 10, 1333-1340. [CrossRef]

81. Krantz, D. Shmita Revolution: The Reclamation and Reinvention of the Sabbatical Year. Religions 2016, 7, 100. [CrossRef]

82. Durkheim, É. The Elementary Forms of the Religious Life; George Allen and Unwin Limited: London, UK, $1915 ;$ pp. 1-456.

83. Berry, E. Religion and Sustainability in Global Civil Society: Some Basic Findings from Rio+20. Worldviews Glob. Relig. Cult. Ecol. 2014, 18, 269-288. [CrossRef]

84. Voyé, L. Secularization in a Context of Advanced Modernity. Sociol. Relig. 1999, 60, 275-288. [CrossRef]

85. King, M.L., Jr. Strength to Love; William Collins + World Publishing Co.: Cleveland, OH, USA, 1963.

86. United Nations. Framework Convention on Climate Change. Admitted NGOs: Constituencies. Available online: unfccc.int/process-and-meetings/parties-non-party-stakeholders/non-party-stakeholders/admitted-ngos\#constituencies (accessed on 20 January 2019). 
87. United Nations. Framework Convention on Climate Change. Admitted NGOs. Available online: unfccc.int/process/parties-nonparty-stakeholders/non-party-stakeholders/admitted-ngos/list-of-admitted-ngos (accessed on 1 May 2019).

88. Native Women's Association of Canada. About Us. Available online: nwac.ca/home/about-nwac/about-us/ (accessed on 1 May 2019).

89. Brewer, D.J. The United States: A Christian Nation; John C. Winston Company: Philadelphia, PA, USA, 1905; pp. 1-98.

90. Egleston, B.L.; Miller, S.M.; Meropol, N.J. The Impact of Misclassification Due to Survey Response Fatigue on Estimation and Identifiability of Treatment Effects. Stat. Med. 2011, 30, 3560-3572. [CrossRef]

91. Steeh, C.G. Trends in Nonresponse Rates, 1952-1979. Public Opin. Q. 1981, 45, 40-57. [CrossRef]

92. Bush, E. The Problem of Categories: Exploring Religion and NGOs through Survey Research. In Religion, NGOs and the United Nations: Visible and Invisible Actors in Power; Carrette, J., Miall, H., Eds.; Bloomsbury Academic: London, UK; New York, NY, USA, 2017; pp. 39-52.

93. United Nations. Framework Convention on Climate Change. Conference of the Parties-Twenty-Fourth Session-Katowice, 2-14 December 2018-Provisional List of Registered Participants; United Nations: Geneva, Switzerland, 2018.

94. World Council of Churches. What is the World Council of Churches? Available online: oikoumene.org/en/about-us (accessed on 1 May 2019).

95. International Association of Oil and Gas Producers. Our Members. Available online: iogp.org/members/ (accessed on 1 May 2019).

96. Berry, Evan. Climate Change and Global Religious Pluralism. In Emergent Religious Pluralisms; Bock, J.-J., Fahy, J., Everett, S., Eds.; Palgrave Macmillan: London, UK, 2019; pp. 279-301.

97. Boehle, J. Religious NGOs at the UN and the Millennium Development Goals: An Introduction. Global Chang. Peace Security 2010, 22, 275-296. [CrossRef]

98. Trigeaud, S.-H. Religious NGOs, UN Participation and Fieldwork Methodology. In Religion, NGOs and the United Nations: Visible and Invisible Actors in Power; Carrette, J., Miall, H., Eds.; Bloomsbury Academic: London, UK; New York, NY, USA, 2017; pp. 73-86.

99. Islamic Relief. Islamic Relief are off to Katowice, Poland for the CoP 24. Available online: islamic-relief.org/climatechange (accessed on 18 October 2019).

100. Islamic Relief. Making an Impact at COP21. Available online: islamic-relief.org/making-an-impact-at-cop21/ (accessed on 18 October 2019).

101. Årsheim, H. Religion and International Organizations. In The Oxford Handbook of International Organizations; Hurd, I., Johnstone, I., Katz Cogan, J., Eds.; Oxford University Press: Oxford, UK, 2016; pp. 490-507.

102. Green Hevra. Gleanings from Our Field: Green Hevra Report 2014. Green Hevra: New York, NY, USA, 2014, pp. 1-16. Available online: aytzim.org/resources/research/377 (accessed on 18 October 2019).

103. Arbuckle, M.B.; Konisky, D.M. The Role of Religion in Environmental Attitudes. Soc. Sci. Q. 2015, 96, 1244-1263. [CrossRef]

104. Greeley, A. Religion and Attitudes toward the Environment. J. Sci. Study Relig. 1993, 32, 19-28. [CrossRef]

105. Hand, C.M.; Van Liere, K.D. Religion, Mastery-Over-Nature, and Environmental Concern. Soc. Forces 1984, 63, 555-570. [CrossRef]

106. Leopold, A. A Sand County Almanac, and Sketches Here and There; Oxford University Press: New York, NY, USA, 1949 ; pp. 1-226.

107. Hitzhusen, G.E.; Tucker, M.E. The Potential of Religion for Earth Stewardship. Front. Ecol. Environ. 2013, 11, 368-376. [CrossRef]

108. Tucker, M.E.; Grim, J. Preface. In Worldviews and Ecology: Religion, Philosophy, and the Environment; Tucker, M.E., Grim, J., Eds.; Orbis Books: Maryknoll, NY, USA, 1994; pp. 11-13.

109. Taylor, B. A Green Future for Religion? Futures 2004, 36, 991-1008. [CrossRef]

110. Grim, J.; Tucker, M.E. Intellectual and Organizational Foundations of Religion and Ecology. In Grounding Religion: A Field Guide to the Study of Religion and Ecology, 1st ed.; Bauman, W., Bohannon, R., O’Brien, K.J., Eds.; Routledge: New York, NY, USA, 2011; pp. 81-95.

111. Braveboy-Wagner, J.A. Institutions of the Global South; Routledge: London, UK; New York, NY, USA, 2009 ; pp. 1-249.

112. King, A.D.; Harrington, L.J. The Inequality of Climate Change from 1.5 to $2{ }^{\circ} \mathrm{C}$ of Global Warming. Geophys. Res. Lett. 2018, 45 , 5030-5033. [CrossRef]

113. Pew Research Center. Global Religious Diversity: Half of the Most Religiously Diverse Countries Are in Asia-Pacific Region; Pew Research Center: Washington, DC, USA, 2014; pp. 1-23.

114. Murray, A. The Later Middle Ages. In Christianity: Two Thousand Years; Harries, R., Mayr-Harting, H., Eds.; Oxford University Press: Oxford, UK, 2001; p. 107.

115. Chidester, D. Savage Systems: Colonialism and Comparative Religion in Southern Africa; University of Virginia Press: Charlottesville, VA, USA, 1996.

116. Chidester, D. Empire of Religion: Imperialism and Comparative Religion; University of Chicago Press: Chicago, IL, USA, 2014.

117. Brons, L.L. Othering, an Analysis. Transci. J. Glob. Stud. 2015, 6, 69-90.

118. Disney, L.R. Associations between Humanitarianism, Othering, and Religious Affiliation. Soc. Work Christ. 2017, $44,60-74$.

119. Roberts, J.T.; Parks, B.C. A Climate of Injustice: Global Inequality, North-South Politics, and Climate Policy; MIT Press: Cambridge, UK; London, UK, 2006; pp. 1-404.

120. United Nations Framework Convention on Climate Change. Fact Sheet: Poznań-COP 14/CMP 4; United Nations: Bonn, Germany, 2008; pp. 1-3. 
121. Grosse, C.; Mark, B. A Colonized COP: Indigenous Exclusion and Youth Climate Justice Activism at the United Nations Climate Change Negotiations. J. Hum. Rights Environ. 2020, 11, 146-170. [CrossRef]

122. United Nations Framework Convention on Climate Change. Past Conferences Overview. Available online: unfccc.int/processand-meetings/conferences/past-conferences/past-conferences-overview (accessed on 24 March 2021).

123. United Nations Framework Convention on Climate Change. Report of the Conference of the Parties on its Second Session, Held at Geneva from 8 to 19 July 1996. Available online: unfccc.int/cop3/resource/docs/cop2/15.htm (accessed on 24 March 2021).

124. United Nations Framework Convention on Climate Change. Berlin Climate Change Conference. March 1995. Available online: unfccc.int/process-and-meetings / conferences/past-conferences/berlin-climate-change-conference-march-1995 (accessed on 24 March 2021).

125. Pew Research Center. The Age Gap in Religion Around the World; Pew Research Center: Washington, DC, USA, 2018 ; pp. 1-97.

126. Kohut, A.; Stokes, B. America Against the World: How We Are Different and Why We Are Disliked; Times Books: New York, NY, USA, 2006.

127. Hurd, E.S. Beyond Religious Freedom: The New Global Politics of Religion; Princeton University Press: Princeton, NJ, USA; Oxford, $\mathrm{UK}, 2017$.

128. Haynes, J. Donald Trump, "Judeo-Christian Values," and the "Clash of Civilizations". Rev. Faith Int. Aff. 2017, 15, 66-75. [CrossRef]

129. Haynes, J. Trump and the Politics of International Religious Freedom. Religions 2020, 11, 385. [CrossRef]

130. Funk, C.; Alper, B.A. Religion and Science: Highly Religious Americans Are Less Likely than Others to See Conflict between Faith and Science; Pew Research Center: Washington, DC, USA, 2015; pp. 1-64.

131. Zaleha, B.D.; Szasz, A. Why Conservative Christians Don't Believe in Climate Change. Bull. At. Sci. 2015, 71, 19-30. [CrossRef]

132. Mills, S.B.; Rabe, B.G.; Borick, C. Acceptance of Global Warming Rising for Americans of All Religious Beliefs. Natl. Surv. Energy Environ. 2015, 1-10.

133. Buckley, D.T. Religious Elite Cues, Internal Division, and the Impact of Pope Francis' Laudato Si'. Politics Relig. 2020, 1-33. [CrossRef]

134. Gecewicz, C.; Smith, G.A.; Cox, K.; Cooperman, A.; Mohamed, B.; Podrebarac Sciupac, E.; Alper, B.A.; Starr, K.J. Americans Have Positive Views about Religion's Role in Society, but Want It Out of Politics; Pew Research Center: Washington, DC, USA, 2019; pp. $1-57$.

135. Hackett, C.; Stonawski, M. The Changing Global Religious Landscape; Pew Research Center: Washington, DC, USA, 2017.

136. Djernaes, M.; Jorgensen, T.; Koch-Ya'ari, E. Evaluation of Environmental Peacemaking Intervention Strategies in Jordan-PalestineIsrael. J. Peacebuild. Dev. 2015, 10, 74-80. [CrossRef]

137. Conca, K.; Dabelko, G.D. Environmental Peacemaking; Woodrow Wilson Center Press: Washington, DC, USA, $2002 ;$ pp. 1-244.

138. Farag, M. Can Water Mitigate the Palestinian-Israeli Conflict? The Case for Environmental Peacemaking. Arab World Geogr. 2018, 21, 299-317. 